Article

\title{
Impulsive Signals Produced by Earthquakes in Italy and Their Potential Relation with Site Effects and Structural Damage
}

\author{
Deniz Ertuncay $^{1, *(D)}$, Petra Malisan ${ }^{2}$ (D) Giovanni Costa ${ }^{1}$ (D) and Stefano Grimaz ${ }^{2}$ (D) \\ 1 SeisRaM Working Group, Department of Mathematics and Geosciences, University of Trieste, \\ Via Eduardo Weiss 4, 34128 Trieste, Italy; costa@units.it \\ 2 Safety and Protection Intersectoral Laboratory-SPRINT-Lab, University of Udine, Via del Cotonificio 114, \\ 33100 Udine, Italy; petra.malisan@uniud.it (P.M.); stefano.grimaz@uniud.it (S.G.) \\ * Correspondence: dertuncay@units.it
}

check for updates

Citation: Ertuncay, D.; Malisan, P.; Costa, G.; Grimaz, S. Impulsive Signals Produced by Earthquakes in Italy and Their Potential Relation with Site Effects and Structural Damage. Geosciences 2021, 11, 261. https://doi.org/10.3390/

geosciences 11060261

Academic Editors: Enrico Priolo and Jesus Martinez-Frias

Received: 10 May 2021

Accepted: 17 June 2021

Published: 21 June 2021

Publisher's Note: MDPI stays neutral with regard to jurisdictional claims in published maps and institutional affiliations.

Copyright: (c) 2021 by the authors. Licensee MDPI, Basel, Switzerland. This article is an open access article distributed under the terms and conditions of the Creative Commons Attribution (CC BY) license (https:// creativecommons.org/licenses/by/ $4.0 /)$.

\begin{abstract}
Near fault seismic records may contain impulsive motions in velocity-time history. The seismic records can be identified as impulsive and non-impulsive depending on the features that their waveforms have. These motions can be an indicator of directivity or fling step effect, and they may cause dangerous effects on structures; for this reason, there is increasing attention on this subject in the last years. In this study, we collect the major earthquakes in Italy, with a magnitude large or equal to $M_{w} 5.0$, and identify the impulsive motions recorded by seismic stations. We correlate impulsive motions with directivity and fling step effects. We find that most earthquakes produced impulsive signals due to the directivity effect, though those at close stations to the 30 October 2016 Amatrice earthquake might be generated by the fling step effect. Starting from the analyzed impulses, we discuss on the potential influence of site effects on impulsive signals and suggest a characterization based on the main displacement directions of the impulsive horizontal displacements. Finally, we discuss on the damage of three churches in Emilia, which were subject to impulsive ground motion, underlying in a qualitative way, how the characteristics of the pulses may have had influences the structural response of the façades.
\end{abstract}

Keywords: near-fault ground motion; impulsive signal; ground motion-damage relation

\section{Introduction}

Impulsive ground motions occur, usually near neighboring regions of the ruptured fault. Due to their proximity to the fault plane, instead of a point source approach to the earthquake, a planar source is implemented in order to understand the evolution of the rupture linked with the impulsive signal. When the rupture front propagates towards a site of interest and the slip direction is facing the site, the forward directivity effect is observed at the site of interest. It happens due to the cumulative effect of the seismic motions. When the rupture propagates to the direction of the site-of-interest with a propagation velocity close to the shear wave velocity of the medium, rupture front contains all seismic energy [1]. Another driving force of the production of an impulsive motion is the permanent displacement of the ground, also known as the fling step effect [2]. When one of these phenomenons is present, large amplitude and long period waveforms are recorded at sites in velocity-time history. Fling step effect can be visible on displacementtime history. It can be seen in strike parallel and strike normal components for strike slip and dip-slip earthquakes, respectively [3]. In an ideal environment, forward directivity would create velocity pulses with half-cycle(s) (due to Gaussian-like displacement of the ground), whereas fling step effect create Gaussian-like velocity pulse (due to the permanent shift of the ground), and these effects can be seen in both strike normal and strike parallel components [4].

Impulsive signals can increase the damage of structures and infrastructure located in near fault regions; this has been evidenced after many earthquakes and analyzed in 
various studies [5-15]. Research on the effects of impulsive ground motion on engineered structures is quite well developed; a short, non-exhaustive review, that can be used as a starting point for further research studies, points out works concerning different structural typologies, namely: seismically base-isolated structures [16-20], bridges [21-25], reinforce concrete or steel moment designed structures [5,26-29], and low- and mid-rise masonry buildings [30]. In Italy, extensive damage occurred mainly where the structures were old and built without engineering design; such situations occur commonly in historical centers and heritage buildings, such as churches and bell towers; anyhow, the damage was also recognized in buildings with engineering design. Concerning L'Aquila earthquake in 2009, the above mentioned issues are the subject of many research papers, which can be classified according to structural typologies, namely: masonry and reinforce concrete buildings [31-36], industrial facilities and lifelines [36], and churches [37,38]. Then, for the Emilia 2012 earthquake, the next review summarizes the research on damage in different typologies of structures, namely: ordinary buildings [33,39], churches and bell towers [40-42], and industrial facilities [43-45]. Moreover, the Emilia earthquakes highlighted the importance of studying also the effects of the seismic sequence on the cumulative damage [46]. Finally, a review on research concerning the effects on the built environment of the Central Italy earthquake in 2016 is summarized in the papers of Sorrentino et al. [47], Jain et al. [48], Masi et al. [49], and Iervolino et al. [15].

To detect the impulsive signals, various algorithms have been developed. For instance Mavroeidis and Papageorgiou [3] used Gabor wavelets and tuned the variables of the algorithm manually. Baker [50] used a 4th order Daubechies wavelet by using decisionmaking parameters of pulse identifier (PI). Shahi and Baker [51] updated the algorithm by using a new dataset and a new decision-making procedure. Chang et al. [52] used the energy ratio in the area where PGV is measured in the waveform. Ertuncay and Costa [53] used a mixed decision-making algorithm by using the energy ration in both time and frequency domain. Baker [50] and Shahi and Baker [51] analyzed only the horizontal motions, whereas Chang et al. [52] and Ertuncay and Costa [53] also analyzed the vertical motion. The latter is important since it could create large demand on some typologies of buildings [11], and it was identified in many stations in the Amatrice earthquakes (see Results section).

Statistical methods are also applied to impulsive signals to investigate their features. Direct relation between moment magnitude and period of the impulsive signals $\left(T_{p}\right)$ is analyzed [50,54-59]. Fayjaloun et al. [60] defined the relation between the $T_{p}$, rise time, and rupture velocity of the event, shear wave velocity of the ground, and distance parameters between the hypocenter and the site of interest. The probability of observing impulsive signals are also calculated by using various distances and angles, depending on the fault types [51,61,62].

In this article, we first describe the dataset in Section 2. In Section 3, we describe the algorithms that we used for data processing and impulsive signals detection. Results of the study are presented in Section 4, together with their interpretation. We use the results as a starting point for the discussion in the section, where we discuss the potential influence of site effects on impulsive signals, and we propose a characterization of pulses according to their shape in the horizontal displacement. Finally, we show how impulses signals potentially affected the seismic behavior of three churches during the Emilia 2012 earthquake sequence.

\section{Data}

This study uses earthquake catalog and waveforms retrieved from ITACA v3.1 [63,64]. Moreover, macroseismic intensity measures are used to investigate if there is evidence of a correlation between impulsive signals and damage. Italian Parametric Catalogue information is used in this study [65]. The database provides damage information from more than 4800 earthquakes that occurred between 1000 and 2019. We collect the epicentral intensity (Io) values while eliminating the non-numerical codes. 
To analyze the strong ground motions in Italy, earthquakes with magnitudes larger than $M_{w} 5.0$ are chosen. In total, 93 earthquakes (see Supplementary Materials) are selected in the period 1976 and 2019 (Figure 1).

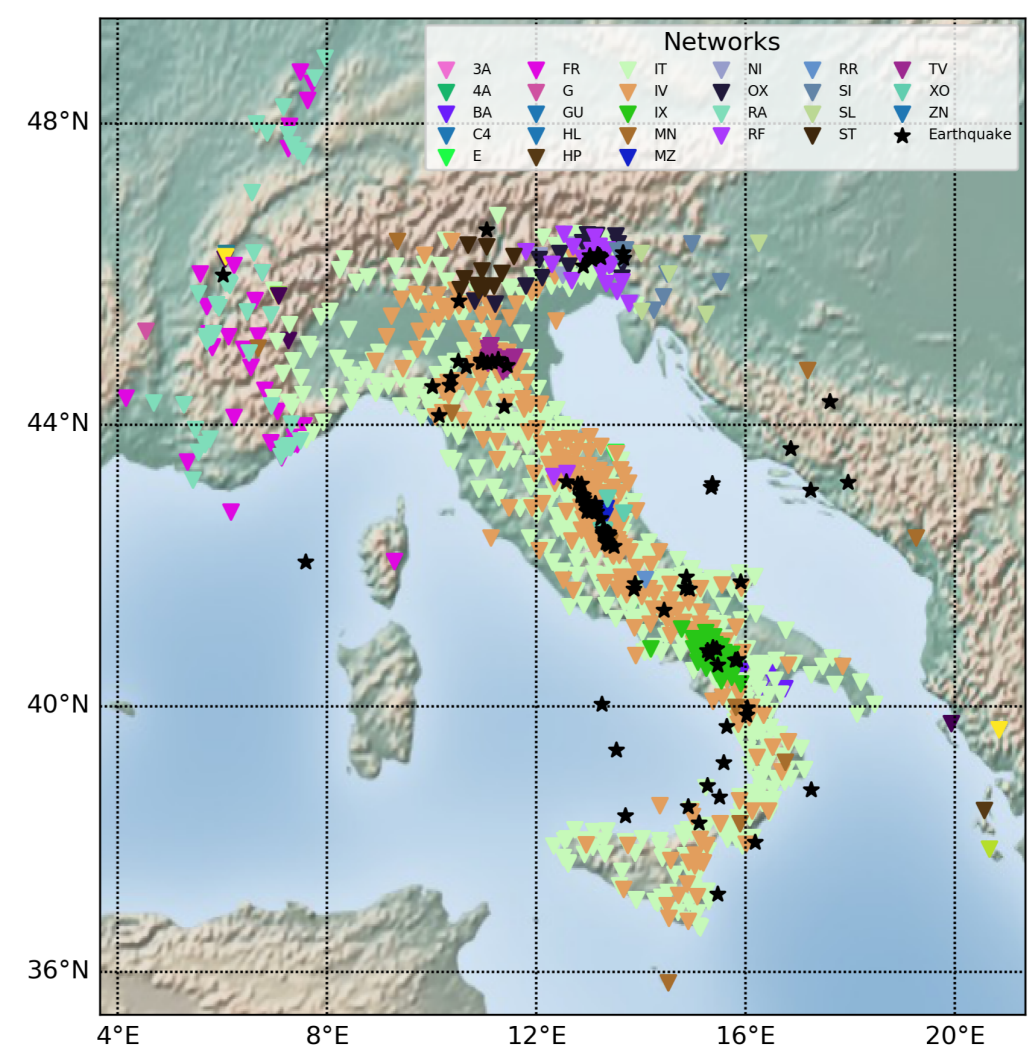

Figure 1. Earthquakes (black stars) and stations (triangles) used in the study.

Signals from ITACA are stored as SAC [66] format. Our dataset contains 15,093 waveforms from 940 stations of 26 networks (Figure 1).

Station records consist of three components of acceleration time histories, recorded along East-West, North-South and vertical directions. However, impulsive signals are easier to detect in fault normal and fault parallel components of horizontal ground motions $[4,67]$. To analyze these motions, we rotated the horizontal channels to the recommended directions. In most of the earthquakes, both auxiliary plane and fault plane information are provided. In earthquake sequences, we selected the closest fault plane to the main shock strike, dip, and rake information. In other cases, we rotated the signals to radial and transverse components. We also used the vertical component to identify vertical impulses. Retrieved signals are preprocessed with the method explained by Paolucci et al. [68].

\section{Method}

Determination of Impulsive Signals

To determine the impulsive signals, we used the algorithms of Shahi and Baker [51], Chang et al. [52], Ertuncay and Costa [53]. These methods are selected due to their unique capabilities to capture impulsive signals by using different approaches and their effectiveness in capturing the impulsive signals on different parts of the waveforms.

The first algorithm is Shahi and Baker [51], which is the improved version of Baker [50]. The classification algorithm uses wavelet-based signal processing on both horizontal channels to determine the impulsive signals. Continuous wavelet transform coefficients are calculated for the given horizontal signals, and then the signals are combined linearly after rotating them to the angle where the maximum energy is centered. The combined 
waveform then used for further wavelet analysis. The final decision is made in two steps. First, it calculates PC as in Equation (1).

$$
\mathrm{PC}=0.63 \times(\mathrm{PGV} \text { ratio })+0.777 \times(\text { energy ratio }) .
$$

"PGV ratio" indicates the ratio of the PGV value of the residual signal and the PGV value of the original signal, where the residual signal is calculated by subtracting the original signal from that produced by the 4 th order Daubechies wavelet signal. "energy ratio" is the ratio calculated by dividing the power of the residual signal by the power of the original signal. In the second stage, PI is calculated as Equation (2).

$$
\mathrm{PI}=9.384 \times(0.76-\mathrm{PC}-0.00616 \times \mathrm{PGV}) \times\left(\mathrm{PC}+6.914 \times 10^{-4} \times \mathrm{PGV}-1.072\right)-6.179 .
$$

If PI is larger than 0 , the given signals are considered impulsive signals, and then the 4th order Daubechies wavelet is fitted to the entire waveforms. Even though Shahi and Baker [51] is a powerful tool to determine impulsive signals, it is not able to detect vertical pulses due to its two component data requirement. The algorithm can differentiate early and late arrival pulses by analyzing the arrival of PGV. Early arrivals of PGV generally indicate a directivity effect [51].

The second algorithm is Chang et al. [52], which is the improved version of Zhai et al. [69]. It is an energy-based classification algorithm. The algorithm determines a region around the PGV and the energy ratio between the pulse region and the total energy of the signal by taking the squared values on both signals. The region around PGV is calculated using a least-square fitting for various pulse periods, and then the one with the smallest residual is used for the pulse region. The energy ratio is then calculated as Equation (3).

$$
E=\frac{\int_{t_{s}}^{t_{e}} v^{2}(\tau) d \tau}{\int_{0}^{\infty} v^{2}(\tau) d \tau} .
$$

If the ratio between the pulse region energy, the numerator of Equation (3), and the total energy, the denominator of Equation (3), exceeds 0.34, the signal is considered as a pulse-shaped signal. $t_{s}$ and $t_{e}$ represent the starting and ending points of the impulse part in the time axis and $v$ represents the velocity-time history of the signal. According to Chang et al. [52], if PGV is less than $30 \mathrm{~cm} / \mathrm{s}$, it is considered a non-hazardous signal for the built environment regardless of the outcome of Equation (3). Chang et al. [52] treats the waveforms individually. Hence, it is able to detect vertical impulsive signals.

The third, and the last, algorithm is Ertuncay and Costa [53]. The algorithm uses both velocity-time history $(v)$ and frequency domain data to analyze signals. The period of the maximum value of the wavelet power spectrum (WPS) determines the impulsive part of the waveform by identifying an area called the PGV area. The position of PGV is the middle point of the area, and its limits are determined by the period of the maximum value of WPS by going backwards and forwards in time with the length of half of the period. Ertuncay and Costa [53] uses the $30 \mathrm{~cm} / \mathrm{s}$ threshold similar to Chang et al. [52]. If the given velocity waveform exceeds the threshold and the average of the energy ratio of the waveform in time and frequency domains is larger than 0.3 , the signal is identified as impulsive (Equation (4)).

$$
\frac{\left(\frac{\int_{t}^{t_{e}} \sigma^{2}(\tau) d \tau}{\int_{0}^{\alpha} v^{2}(\tau) d \tau}+\frac{\int_{t_{\mathrm{s}}}^{t_{e}} \operatorname{WPS}(\tau) d \tau}{\int_{0}^{\infty} \operatorname{WPS}(\tau) d \tau}\right)}{2} \geq 0.30 .
$$

If the impulsive part is located outside of the PGV area, several extra constraints are applied to the decision-making algorithm. The energy of the region must be $10 \%$ or higher than the energy of the PGV area both in time and frequency domain, and the maximum amplitude of the region must be larger than $25 \mathrm{~cm} / \mathrm{s}$ (see Ertuncay and Costa [53] for further information on the definition of the threshold values). If the region exceeds 
these constraints and satisfies the Equation (4), then the signal is considered impulsive. The algorithm has similarity with Chang et al. [52] in terms of using an energy threshold for decision-making. Ertuncay and Costa [53], unlike Chang et al. [52], can detect impulsive signals that are occurring outside of the PGV area.

\section{Results}

In this section, we provide the impulsive signals determined by the algorithms explained in the Method Section, where 15093 waveforms with fault normal, fault parallel, and vertical orientation are analyzed in terms of their impulsiveness. Shahi and Baker [51] algorithm, unlike the others, used only the horizontal components to detect impulsive signals. Shahi and Baker [51], Chang et al. [52], Ertuncay and Costa [53] identified 29, 57, and 51 impulsive signals from 13 earthquakes, respectively. Chang et al. [52] and Ertuncay and Costa [53] identified 9 and 8 vertical impulsive signals from two earthquakes (Table 1), respectively. Faulting mechanisms of earthquakes that produced impulsive motions are normal and reverse faults.

Table 1. Number of impulsive signals detected by Shahi and Baker [51], Chang et al. [52], and Ertuncay and Costa [53].

\begin{tabular}{|c|c|c|c|c|c|}
\hline \multirow{2}{*}{ ITACA_ID } & \multirow{2}{*}{ Shahi and Baker [51] } & \multirow{2}{*}{\multicolumn{2}{|c|}{$\begin{array}{l}\text { Chang et al. [52] } \\
\text { Horizontal Vertical }\end{array}$}} & \multicolumn{2}{|c|}{ Ertuncay and Costa [53] } \\
\hline & & & & Horizontal & Vertical \\
\hline IT-1976-0025 & 2 & 1 & 0 & 1 & 0 \\
\hline IT-1976-0027 & 1 & 1 & 0 & 1 & 0 \\
\hline IT-1976-0030 & 1 & 1 & 0 & 1 & 0 \\
\hline IT-1980-0012 & 2 & 3 & 0 & 3 & 0 \\
\hline IT-2009-0009 & 4 & 6 & 0 & 6 & 0 \\
\hline IT-2012-0008 & 1 & 2 & 0 & 2 & 0 \\
\hline IT-2012-0010 & 1 & 2 & 0 & 2 & 0 \\
\hline IT-2012-0011 & 6 & 9 & 0 & 9 & 0 \\
\hline IT-2012-0012 & 2 & 1 & 0 & 1 & 0 \\
\hline EMSC-20160824_0000006 & 2 & 2 & 1 & 1 & 1 \\
\hline EMSC-20161026_0000077 & 1 & 1 & 0 & 1 & 0 \\
\hline EMSC-20161026_0000095 & 1 & 2 & 0 & 2 & 0 \\
\hline EMSC-20161030_0000029 & 5 & 17 & 8 & 14 & 7 \\
\hline
\end{tabular}

Impulsive signals detected by the algorithm of Shahi and Baker [51] have PGV varying between $8.2 \mathrm{~cm} / \mathrm{s}$ to $72.1 \mathrm{~cm} / \mathrm{s}$. We calculated the distance from a seismic station to the surface projection of the rupture surface of the earthquake $\left(R_{j b}\right)$ of the stations. $R_{j b}$ distance requires rupture plane and focal mechanisms, unlike epicentral distance, which only requires the epicenter of the earthquake. In Shahi and Baker [51], 13 out of 29 impulsive signals occurred at stations that are located on top of the rupture surface $\left(R_{j b}=0 \mathrm{~km}\right)$, and the maximum $R_{j b}$ distance is $14.6 \mathrm{~km}$ (GUI station of 11 September 1976 Friuli earthquake). $T_{p}$ of the impulsive signals are between $0.52 \mathrm{~s}$ (CMI station of 26 October 2016 Amatrice earthquake) and $3.29 \mathrm{~s}$ (STR station of 23rd of November 1980 Irpinia earthquake).

PGVs of Chang et al. [52] vary between $30.2 \mathrm{~cm} / \mathrm{s}$ and $85 \mathrm{~cm} / \mathrm{s}$ (MZ24 station of 30 October 2016 Amatrice earthquake). In vertical impulsive signals, maximum vertical PGV $(68.6 \mathrm{~cm} / \mathrm{s})$ is measured in CLO station on 30 October 2016 Amatrice earthquake. 18 impulsive signals were recorded on top of the surface rupture, whereas 39 signals were recorded outside of the rupture area with the farthest distance of $12.2 \mathrm{~km}$ (GMN station of 11 September 1976 Friuli earthquake). Pulse periods are between $0.4 \mathrm{~s}$ (various signals from Amatrice earthquake sequence) and $3.8 \mathrm{~s}$ (STR station of 23 November 1980 Irpinia earthquake).

PGVs of impulsive signals detected by Ertuncay and Costa [53] are between $30.2 \mathrm{~cm} / \mathrm{s}$ and $85 \mathrm{~cm} / \mathrm{s}$ (MZ24 station of 30 October 2016 Amatrice earthquake). The maximum PGVs in the vertical impulsive signal are $68.6 \mathrm{~cm} / \mathrm{s}$ (CLO station on 30 October 2016 Amatrice earthquake). Twenty-one of the signals were recorded on top of the rupture surface, and 3 of them were recorded in vertical components of the 30 October 2016 Amatrice earthquake. 
The farthest impulsive signal from the rupture surface has $R_{j b}$ distance of $12.2 \mathrm{~km}$ (GMN station of 11 September 1976 Friuli earthquake). Pulse periods are between $0.5 \mathrm{~s}$ (MZ51 station of 30 October 2016 Amatrice earthquake) and 7.2 s (T1214 station of 30 October 2016 Amatrice earthquake).

We analyze earthquakes that created impulsive signals individually in the following subsections. We investigate the physics of the earthquakes and the local soil conditions to understand the driving forces of the signals. We created station distribution maps for these earthquakes for three different impulsive signal detection algorithms. We present these maps in Supplementary Materials. In the following section, we chose one of the three algorithms to show the spatial distribution of the signal. This decision is made to visually inspect the maps more easily and to keep paper simple.

\subsection{Friuli Earthquakes (IT-1976-0025, IT-1976-0027, IT-1976-0030) and Aftershocks}

Friuli earthquake sequence provides the earliest impulsive signals records in our database. There are 8 earthquakes with reverse fault mechanism recorded by 61 station records and 4 impulsive signals in three earthquakes. Due to the lack of station coverage inside the $R_{j b}$ zone and its surroundings, it is hard to determine the extent of impulsive signals, depending on the azimuth angle and the distance. Impulsive signals are recorded on GMN station in three earthquakes: Figure 2 illustrates both impulsive and non-impulsive signals, together with the macroseismic intensity measurements (from Rovida et al. [65]) assessed for the represented seismic events; however, it must be underlined that most of the damage was caused by the shock of the 6 May 1976. GMN station (that always recorded during the Friuli earthquakes) is only $3 \mathrm{~km}$ south of Venzone which was one of the most severely destroyed towns by the Friuli earthquakes. After the earthquake of the 6 May 1976, the city of Gemona del Friuli (where GMN station is located) sustained a XI degree MCS macroseismic intensity [65]. The town is located on an alluvial fan, which increased the local site effects [70], and could have contributed to the amplification of impulsive signals in the ground motion. The town of Gemona del Friuli suffered from the earthquake intensively, and the GMN station recorded impulsive signals at 3 of the 8 earthquakes in our database.

\subsection{Irpinia Earthquake (IT-1980-0012) and Aftershocks}

Irpinia earthquake and 4 of its aftershocks occurred on a normal fault, and in total 40 stations recorded the seismic waves. Irpinia earthquake has a large rupture area (Figure 3) and created 2 impulsive signals, one of which has the largest $T_{p}$ (between $3.3 \mathrm{~s}$ and $3.8 \mathrm{~s}$, depending on the algorithm) in the STR station. BGI station is also identified as impulsive by all the algorithms. Macroseismic intensity shows that $R_{j b}$ region took high damage by the earthquake; however, there was no installed station when the mainshock occurred. Thus, we are not able to make any further interpretation about the effect of impulsive motions for the earthquake. 

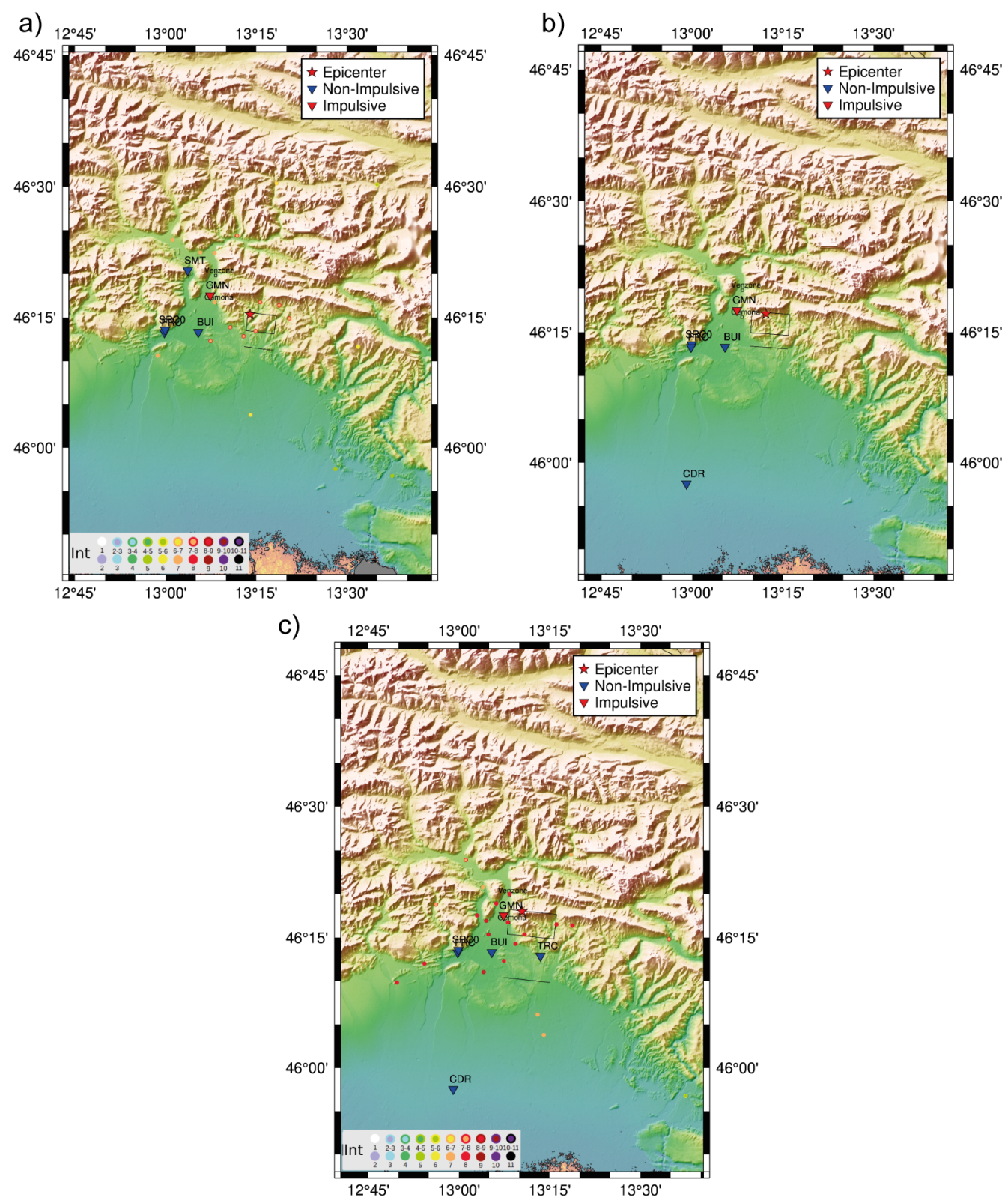

Figure 2. Spatial distribution of impulsive (red triangle) and non-impulsive (blue triangle) signals determined by the algorithm of (a) Shahi and Baker [51], (b) Chang et al. [52], and (c) Ertuncay and Costa [53] for 11 September 1976 (16:35) Friuli $\left(M_{w}=5.6\right)$, 15 September 1976 (03:15) Friuli $\left(M_{w}=5.9\right)$, and 11 September $1976(09: 21)$ Friuli earthquakes $\left(M_{w}=6.0\right)$, respectively. Rupture surface of earthquakes are retrieved from Group et al. [71], and macroseismic intensity (Int) measurements are taken from Rovida et al. [65]. Red star indicates the epicenter of the event. This map and following maps are created by using PyGMT package of python [72], unless specified by other sources. 


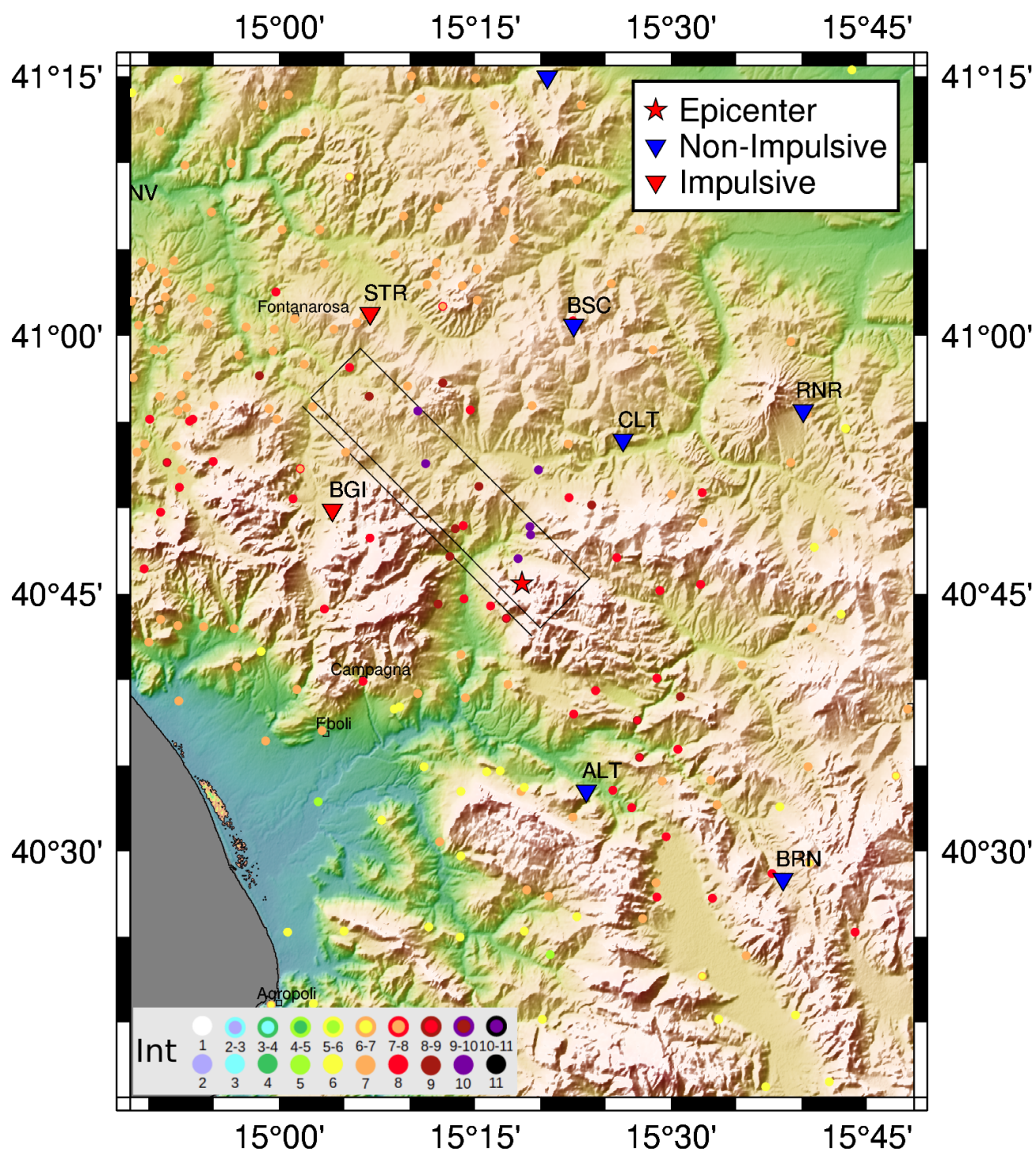

Figure 3. Spatial distribution of impulsive (red triangle) and non-impulsive (blue triangle) signals determined by the algorithm of Shahi and Baker [51] for 23 November 1980 (18:34) Irpinia earthquake $\left(M_{w}=6.9\right)$. Rupture surface is retrieved from Ameri et al. [73] and macroseismic intensity (Int) measurements are taken from Rovida et al. [65]. Red star indicates the epicenter of the event.

\subsection{L'Aquila Earthquake (IT-2009-0009) and Aftershocks}

L'Aquila earthquake sequence is represented by 8 earthquakes (all of them have normal fault mechanism), but only the main event produced impulsive signals. The number of recorded signals is almost 10 times higher than the Irpinia earthquake, and the station coverage is increased significantly, which allows us to better understand the impulsive signals and their nature in Italian territory starting from this earthquake. L'Aquila earthquake produced multiple impulsive signals, which have been recorded by stations located on top of the ruptured fault (on the hanging wall) (Figure 4). Pulse periods calculated in this study are in the range between $0.9 \mathrm{~s}$ and $1.7 \mathrm{~s}$ for $\mathrm{AQK}$ and $\mathrm{AQV}$ stations. These impulsive motions are linked to the site amplification at around $0.6 \mathrm{~Hz}$ [74-76]. Impulsive signals have both similar PGVs (between $34.8 \mathrm{~cm} / \mathrm{s}$ and $44.7 \mathrm{~cm} / \mathrm{s}$ ) and pulse periods, and this is reasonable since these stations are located close to each other, and they are all $\mathrm{B}$ sites according to EC8 [76,77]. Pulses occurred both in fault normal and fault parallel components. The directivity effect can also play a role in these impulsive signals [78]. The slip distribution of the earthquake does not follow the position of the impulsive signals [79]. Ameri et al. [79] shows that a large slip has occurred on the south-east part of the rupture, 
whereas impulsive signals are located at the north-west side. However, the city of L'Aquila suffered from the widespread damage after the earthquake [31,34,38]. It is important to keep in mind that there is a lack of station coverage where the maximum slip has occurred. Moreover, the south-west part of the $R_{j b}$ zone also suffered a large destruction [33,38].

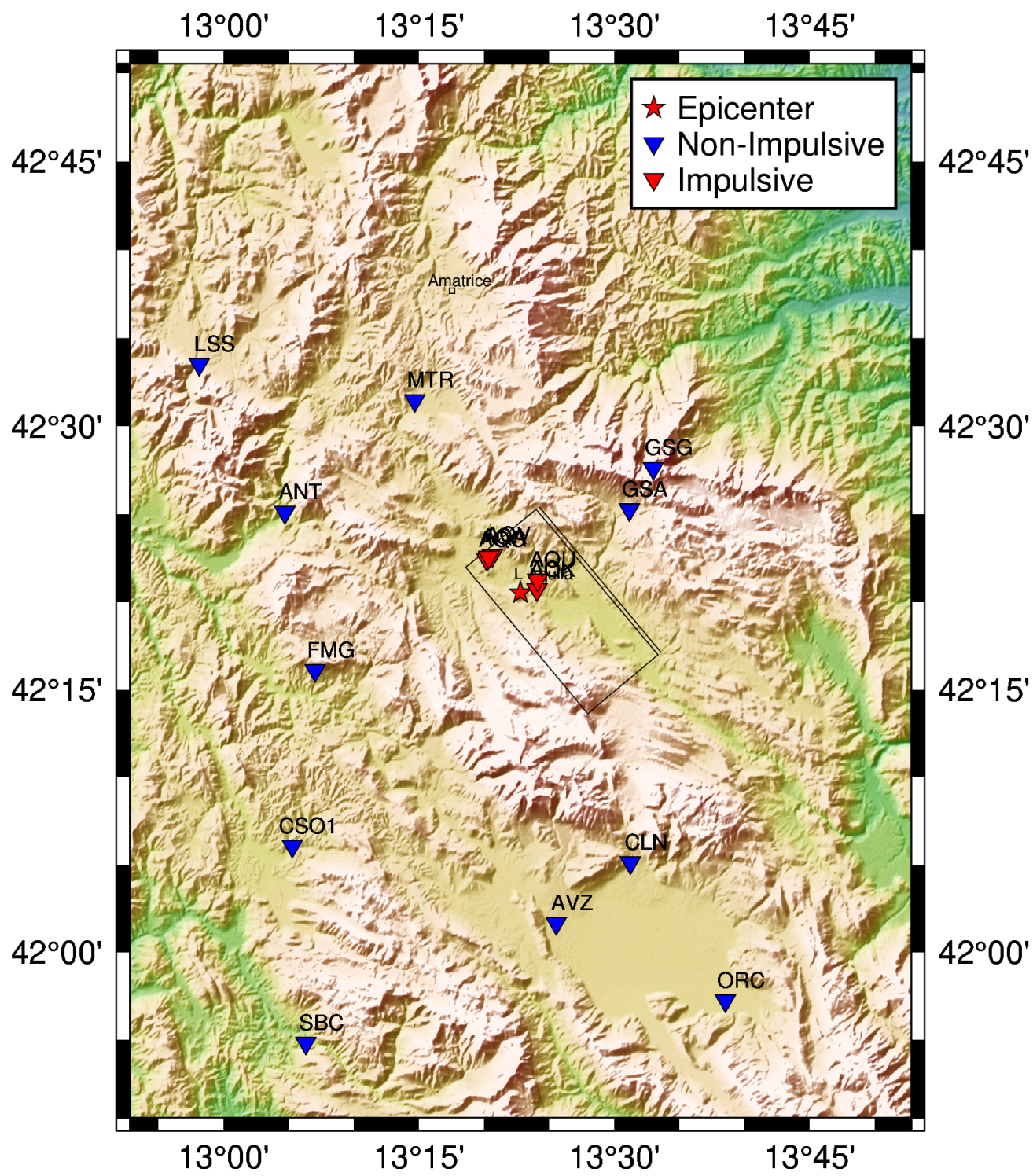

Figure 4. Spatial distribution of impulsive (red triangle) and non-impulsive (blue triangle) signals determined by the algorithm of Chang et al. [52] for 6 April 2009 (01:32) L'Aquila earthquake $\left(M_{w}=6.1\right)$. Rupture surface is retrieved from Ameri et al. [79]. Red star indicates the epicenter of the event.

\subsection{Emilia-Romagna Earthquakes (IT-2012-0008, IT-2012-0010, IT-2012-0011) and Aftershocks}

Emilia-Romagna earthquake sequence is characterized by 10 events (all of them have reverse fault mechanism) that satisfy our magnitude threshold. More than 1500 station records are investigated, and 9 stations recorded impulsive motions (Figure 5). All impulsive signals are on the hanging wall, which is the moving plate on the sequence. In the 20 May 2012 (10:55) Emilia-Romagna earthquake, MRN station is the only station that produced impulsive motions. It is the closest station to the ruptured fault (upper row of Figure 5) with $R_{j b}$ distance of $4.55 \mathrm{~km}$. The station is located on the hanging wall of the fault plane; therefore, MRN location was on the moving plate of the earthquake. The maximum slip of the earthquake is modeled around $1 \mathrm{~m}$ (Figure 5a). 

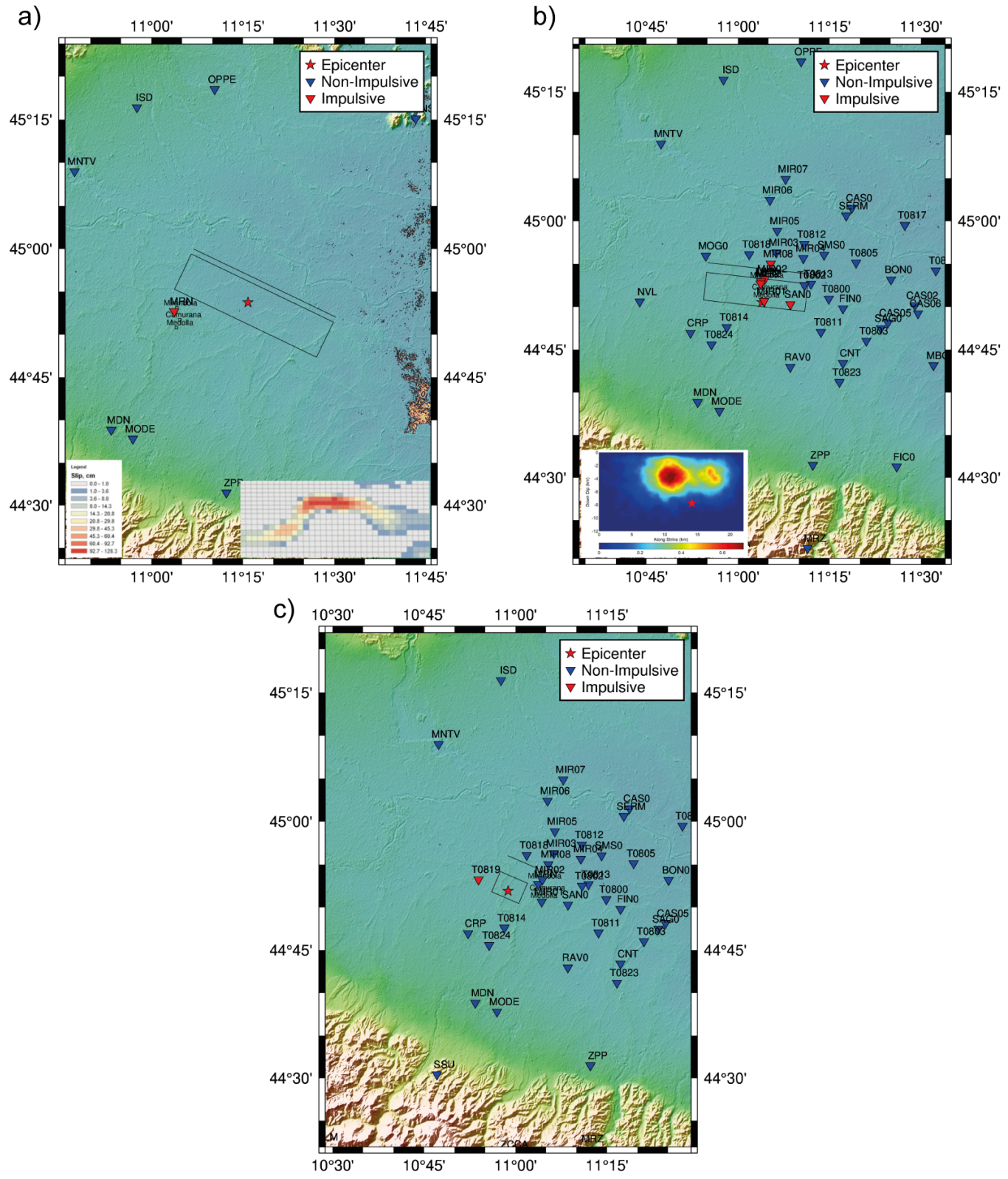

Figure 5. Spatial distribution of impulsive (red triangle) and non-impulsive (blue triangle) signals determined by the algorithm of Ertuncay and Costa [53] for Emilia-Romagna earthquakes of (a) 20 May $2012\left(M_{w}=6.1\right)$, (b) 29 May $2012(07: 00)\left(M_{w}=6.0\right)$, and (c) 29 May $2012(10: 55)\left(M_{w}=5.5\right)$. Rupture surface of earthquakes are retrieved from Pezzo et al. [80], Paolucci et al. [81], Kaklamanos et al. [82], respectively. Slip distribution of 20 May 2012 is modified from Figure S7 of Electronic Supplement of Pezzo et al. [80]. Slip distribution of the 29 May 2012 (07:00) Emilia-Romagna earthquake modeled by Paolucci et al. [81] and can be seen in Figure 8 of the mentioned study. Red star indicates the epicenter of each event.

MRN station has PGV values of $42.2 \mathrm{~cm} / \mathrm{s}$ and $34.2 \mathrm{~cm} / \mathrm{s}$ on fault-normal and faultparallel components, respectively, whereas the vertical motion of the station is much lower $(5.0 \mathrm{~cm} / \mathrm{s})$. Fault normal and fault parallel components of the MRN station are identified by all pulse detection algorithms used in this study. Impulsive feature of the station is also noticed by previous studies [83].

On the 29 May 2012 (07:00) Emilia-Romagna earthquake, MRN station is also one of the many impulsive signals (Figure 5). All the stations (except MIR08) were located on the hanging wall of the fault plane, which can explain the impulsive behavior of these stations since they are, as in the aforementioned earthquake, located on top of the moving plate. 
Many of the impulsive signals are measured by a temporary network installed by INGV, which are named MIR and a dedicated number. All of these stations are aligned along fault normal direction. Some particle motion of the impulsive signal produced sites can be seen in Figure 6. Large horizontal displacements, especially in fault normal direction, can be noticed. In fact, both fault normal and fault parallel channels of MIR01 and MIR02 are identified as impulsive by all the algorithms. Furthermore, in 29 May 2012 (07:00) earthquake, impulsive signals can be connect to the updip directivity effect [81]. Pulse periods that are calculated by the 3 different algorithms that we use vary between $0.6 \mathrm{~s}$ to $3.1 \mathrm{~s}$. The largest period is calculated by Shahi and Baker [51] for MIR02 station in the 29 May 2012 (07:00) earthquake. Fault normal and fault parallel stations are separately investigated by Chang et al. [52], Ertuncay and Costa [53], and both studies identify all horizontal components as impulsive. This earthquake also created widespread damage inside the $R_{j b}$ area and its surroundings [39].

a)
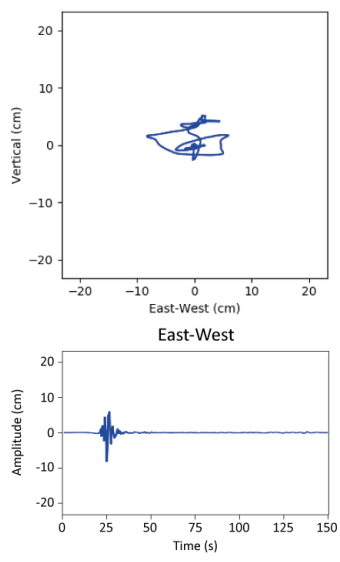

East-West

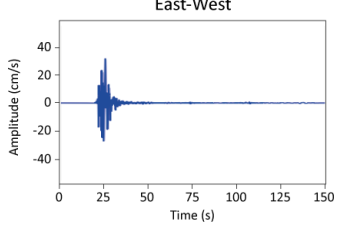

b)
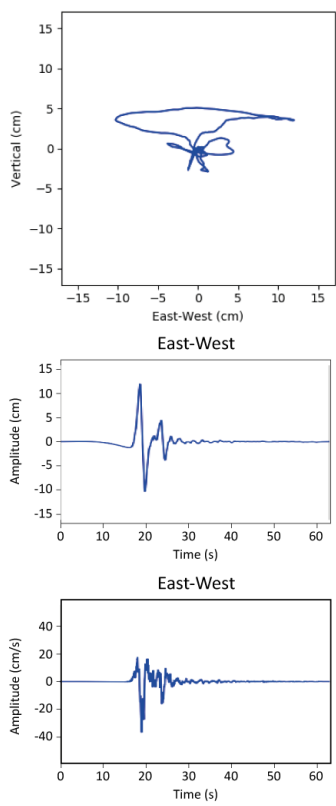

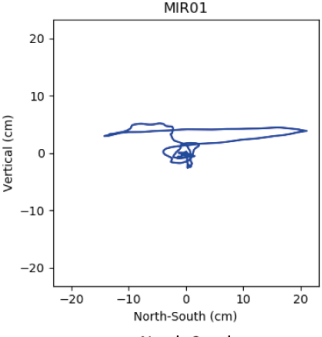

North-South

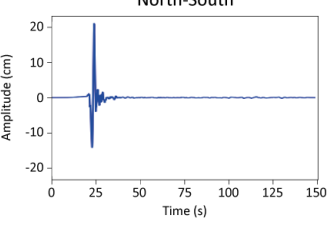

North-South

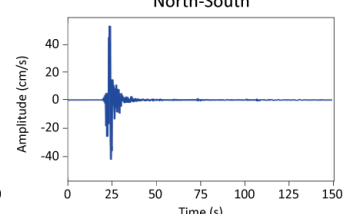

MIRO2
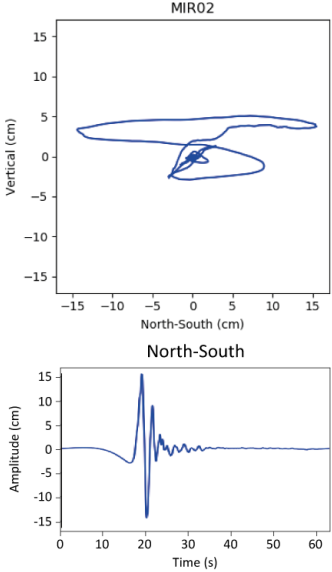

North-South

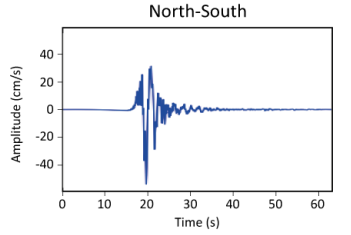

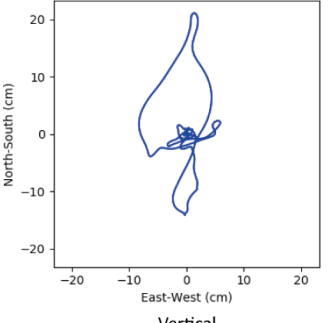

Vertical
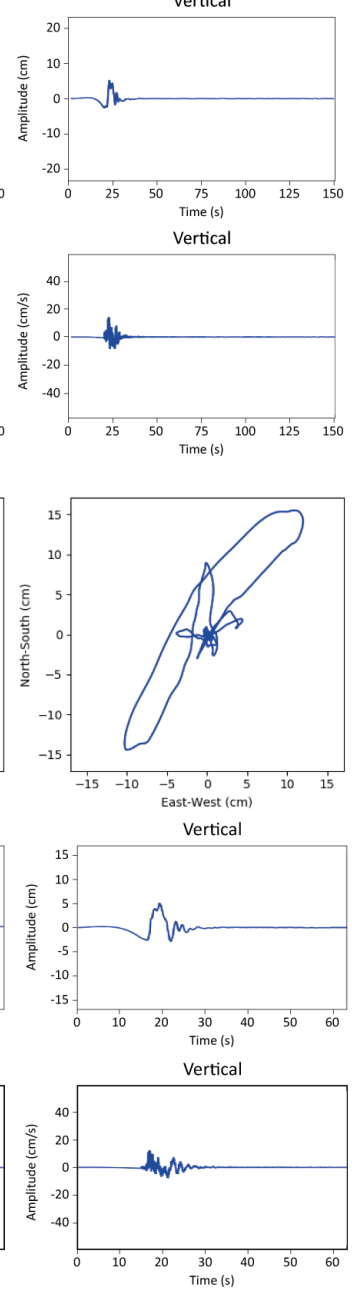

Figure 6. Ground motions of orthogonal components and velocity waveform of (a) MIR01, and (b) MIR02 stations recorded during 29 May 2012 (07:00) Emilia-Romagna earthquake. 
We analyze the aftershocks of the Emilia-Romagna event with $M_{l} \geq 4.0$ and $M_{w} \leq 5.0$ magnitude range to find more impulsive signals. In total, 738 signals from 22 earthquakes are collected. All those signals are preprocessed with the same steps that are explained in Section 3. None of these signals is identified as impulsive by 3 algorithms that we use. However, if we reduce the PGV threshold to $10.0 \mathrm{~cm} / \mathrm{s}$, we would identify several impulsive signals with similar wave patterns with the signals recorded during the bigger magnitude earthquakes of the sequence.

\subsection{Amatrice Earthquakes (EMSC-20160824_0000006, EMSC-20161026_0000077, EMSC-20161026_0000095,EMSC-20161030_0000029) and Aftershocks}

Amatrice earthquake sequence has 9 earthquakes with a normal fault mechanism. In total, 1838 stations recorded the earthquake signals during the sequence, and a large amount of impulsive signals are detected by the pulse classification algorithms. Unlike Emilia-Romagna earthquakes, the Amatrice earthquake sequence is also created a large amount of vertically impulsive motions (Table 1). Amatrice earthquake sequence established a perfect environment for creating impulsive signals by high rupture velocity, directivity, and fling step effect. The directivity effect is the main source of impulsive signals. However, those at close stations to the 30th October 2016 earthquake might be due to the fling step effect because this effect can appear if a station is located close to a shallow earthquake [84]. This earthquake provides $33 \%$ to $50 \%$ of the total number of impulsive signals in our study, depending on the classification algorithm. We also analyze the aftershocks with smaller magnitudes $\left(M_{w} \leq 5.0\right)$ to detect more impulsive signals. Due to the same reason that we come across Emilia-Romagna earthquakes, none of them is labeled as impulsive. During the 24 August 2016 Amatrice earthquake, AMT station recorded impulsive motions by all algorithms, whereas Shahi and Baker [51] also identified NOR station as impulsive (Figure 7). AMT station is located along fault parallel direction, and impulsive motion is recorded by fault parallel component. Gallovič et al. [85] linked the large amplitudes in AMT with the large slip patch that propagated towards the station. Furthermore, study of Spagnuolo et al. [86] found that there is a patch of region in the east of the rupture area (towards AMT) where rupture velocity is close to the shear wave velocity of the medium which can also linked to the directivity effect.

The 30 October 2016 Amatrice earthquake, also called Norcia earthquake and Norcia mainshock of the Amatrice-Norcia-Visso seismic sequence, is the largest earthquake of Amatrice earthquake sequence with $M_{w}=6.5$. It ruptured more than $25 \mathrm{~km}$ along strike and $14 \mathrm{~km}$ along dip with a maximum slip of $2.5 \mathrm{~m}$ (Figure $7 \mathrm{~d}$ ). Unlike other pulse produced earthquakes, the Norcia earthquake produced large amounts of vertical impulsive signals (last row of Figure 7).

Pulse periods calculated by the 3 different algorithms vary between $0.45 \mathrm{~s}$ to $7.2 \mathrm{~s}$. Largest period is calculated by Ertuncay and Costa [53] for T1214 station. Fault normal and fault parallel stations are separately investigated along with the vertical components by Chang et al. [52], Ertuncay and Costa [53]. Both of these studies find a large number of impulsive motions in vertical channels. Two of these stations that recorded vertical impulses can be seen in Figure 8. MZ04 recorded impulsive motions in fault normal (by Chang et al. [52]) and vertical components (by Chang et al. [52], Ertuncay and Costa [53]), whereas horizontal motions of T1214 is labeled as impulsive by all algorithms and vertical component is labeled as impulsive only by Ertuncay and Costa [53]. Impulsive signals are located on the Southern side of the ruptured area. This region has been suffered from the fling step effect [87], and we believe that vertical impulsive motions can be another indicator of the effect. 

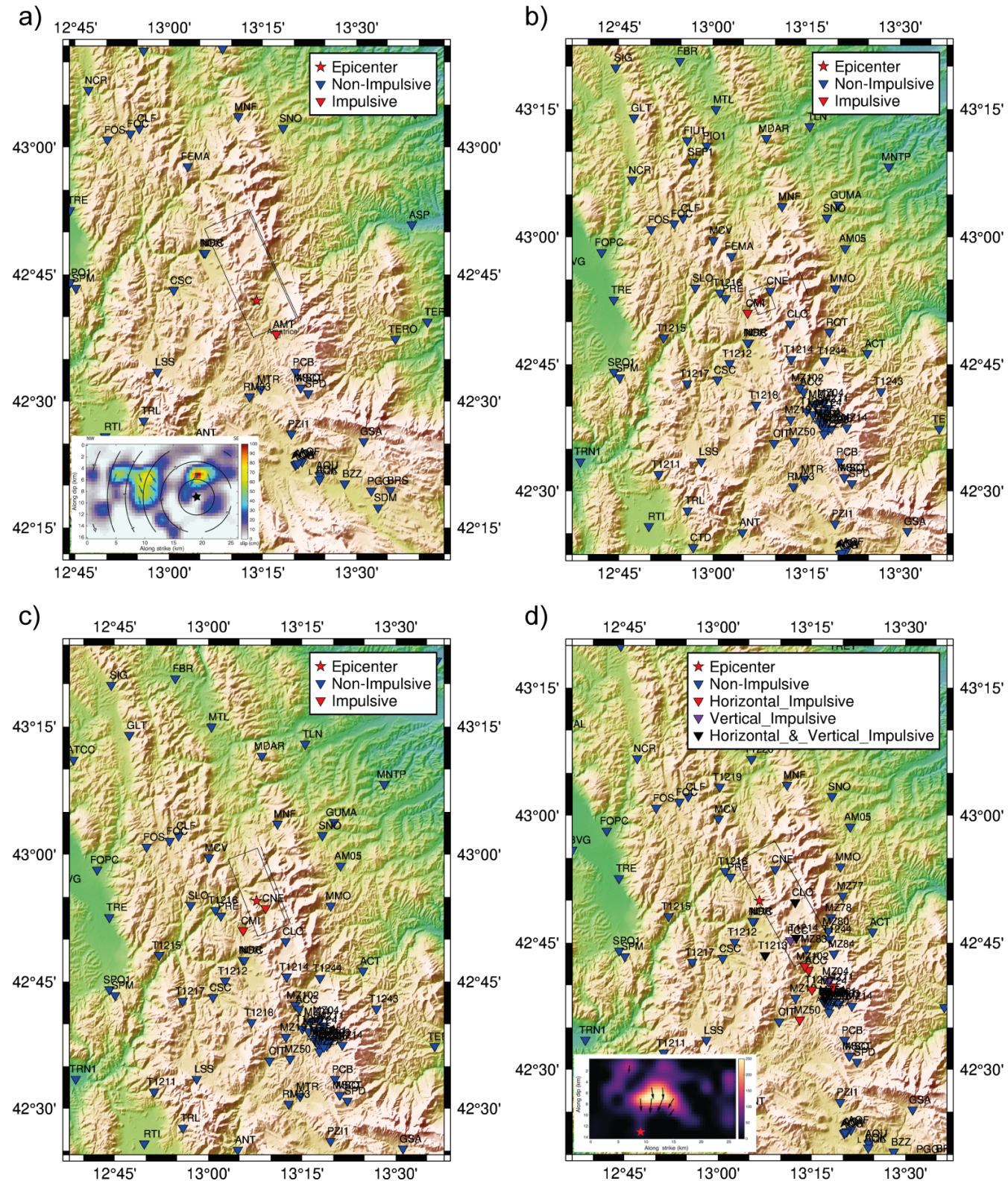

Figure 7. Spatial distribution of horizontal impulsive (red triangle), vertical impulsive (purple triangle), both horizontal and vertical impulsive (black triangle), and non-impulsive signals determined by the algorithm of (a,b) Shahi and Baker [51], and (c,d) Ertuncay and Costa [53] for (a) 24 August 2016 (01:36) Amatrice $\left(M_{w}=6.0\right)$, (b) 26 October 2016 (17:10) Amatrice $\left(M_{w}=5.4\right)$, (c) 26 October 2016 (19:18) Amatrice $\left(M_{w}=5.9\right)$, and (d) 30 October 2016 (06:40) Amatrice earthquakes $\left(M_{w}=6.5\right)$. Rupture surface of EMSC-20160824_0000006 and EMSC-20161026_0000077 are retrieved from Tinti et al. [88] and Kaklamanos et al. [82]. EMSC-20161026_0000095 and EMSC20161030_0000029 are retrieved from Chiaraluce et al. [89]. Slip distribution of 24 August 2016 (01:36) Amatrice earthquake modeled by Tinti et al. [88] and can be seen in Figure 8 of the study. Slip distribution of the 30 October 2016 (06:40) Amatrice earthquake was modeled by Chiaraluce et al. [89] and can be seen in Figure 4c of the mentioned study. Red star indicates the epicenter of the event. 
a)
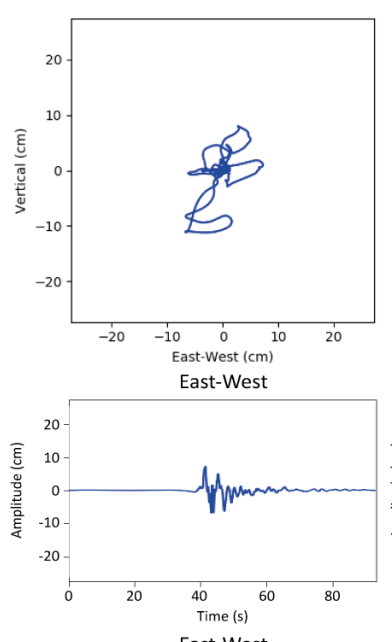

East-West

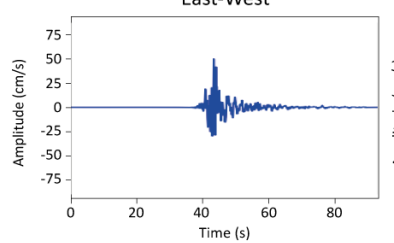

b)
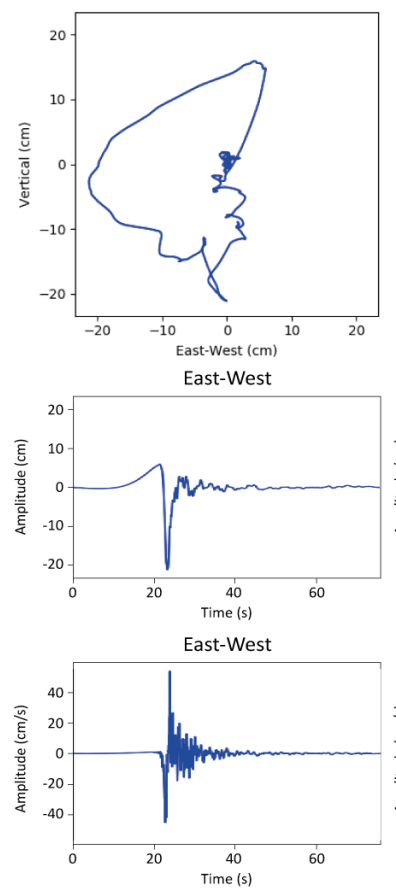

MZ04
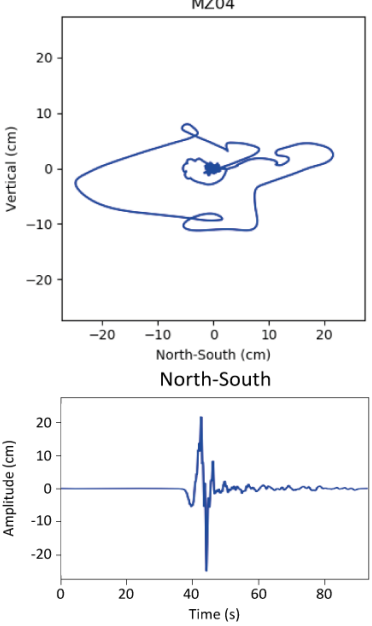

North-South

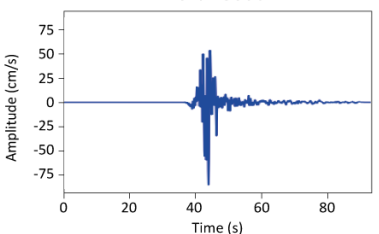

$\mathrm{T} 1214$
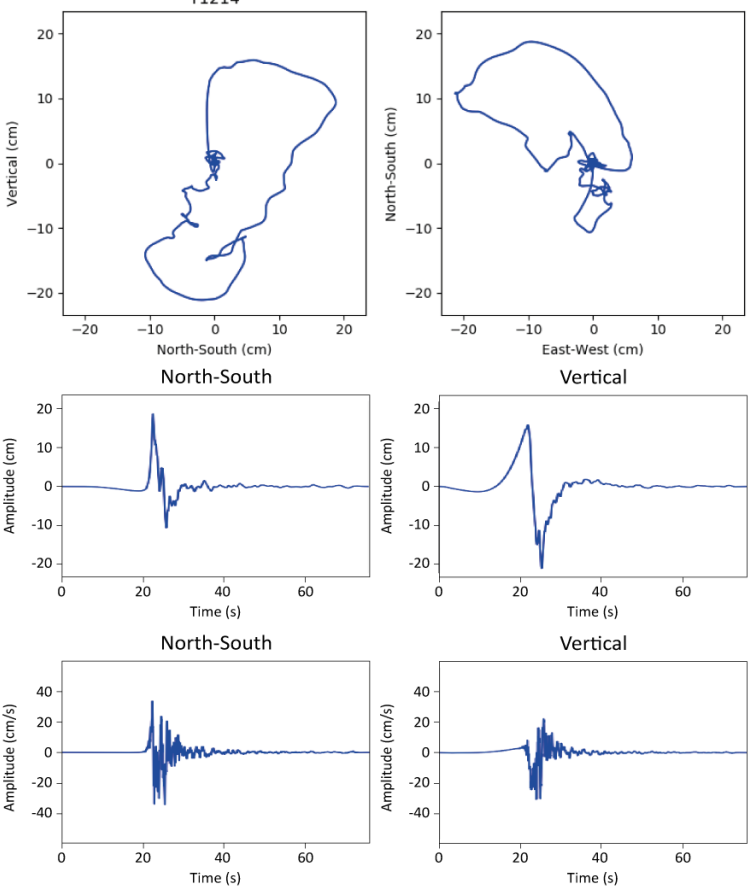

Figure 8. Ground motions of orthogonal components and velocity waveform of (a) MZ04 and (b) T1214 stations in 30 October 2016 (06:40) Amatrice earthquake, respectively.

\section{Discussion}

Recorded impulsive signals in Italian territory are increased in years thanks to the improvement of the seismic networks. Starting from the L'Aquila earthquake, it is possible to make further investigation about the features of the impulsive signals. The analysis of impulsive signals of Italian earthquakes leads to some points of discussion. As mentioned in Section 4.3, it has been observed that local soil conditions may affect the periods of the impulsive signals. The potential correlation between local site effects and seismic impulses has been studied by Bray and Rodriguez-Marek [55], Cork et al. [58], Rodriguez-Marek and Bray [90]. They investigated the effect of soil conditions on pulses, showing that soft 
soils tend to amplify the PGV and increase the period of the pulse for moderate-magnitude near-fault ground motion, thus facilitating the occurrence of pulse-like velocity waveforms of longer periods at soil sites than at rock sites.

It is known that impulsive signals mainly depends on the directivity and on the fling step effects of the earthquake that generated the waveforms. Anyhow, Authors believe that the impulsive ground motion can be further modified by site effects, and this aspect seems to be confirmed by empirical evidence.

Figure 9 shows the horizontal particle displacements recorded during the 29 May 2012 (07:00) Emilia-Romagna earthquake. It is possible to observe that almost all stations in the area of Mirandola show a very similar pattern of the horizontal ground motion, with the presence of a principal direction for the displacement, approximately in the direction North-North East. The motions of the stations that are positioned from North to South (MIR08, MIR02, MIRH, MRN, and MIR01) are in perpendicular alignment with the maximum slip of the earthquake (Figure 5). Motions of the stations are dominated by the North-South movement, which is similar to the slip distribution and the rake angle of 90 degrees. Conversely, if we consider the L'Aquila (Figure 10) and Amatrice (Figure 11) earthquakes, it is possible to observe that the horizontal representation of the impulsive displacement changes significantly in the various sites also with a relatively small distance.

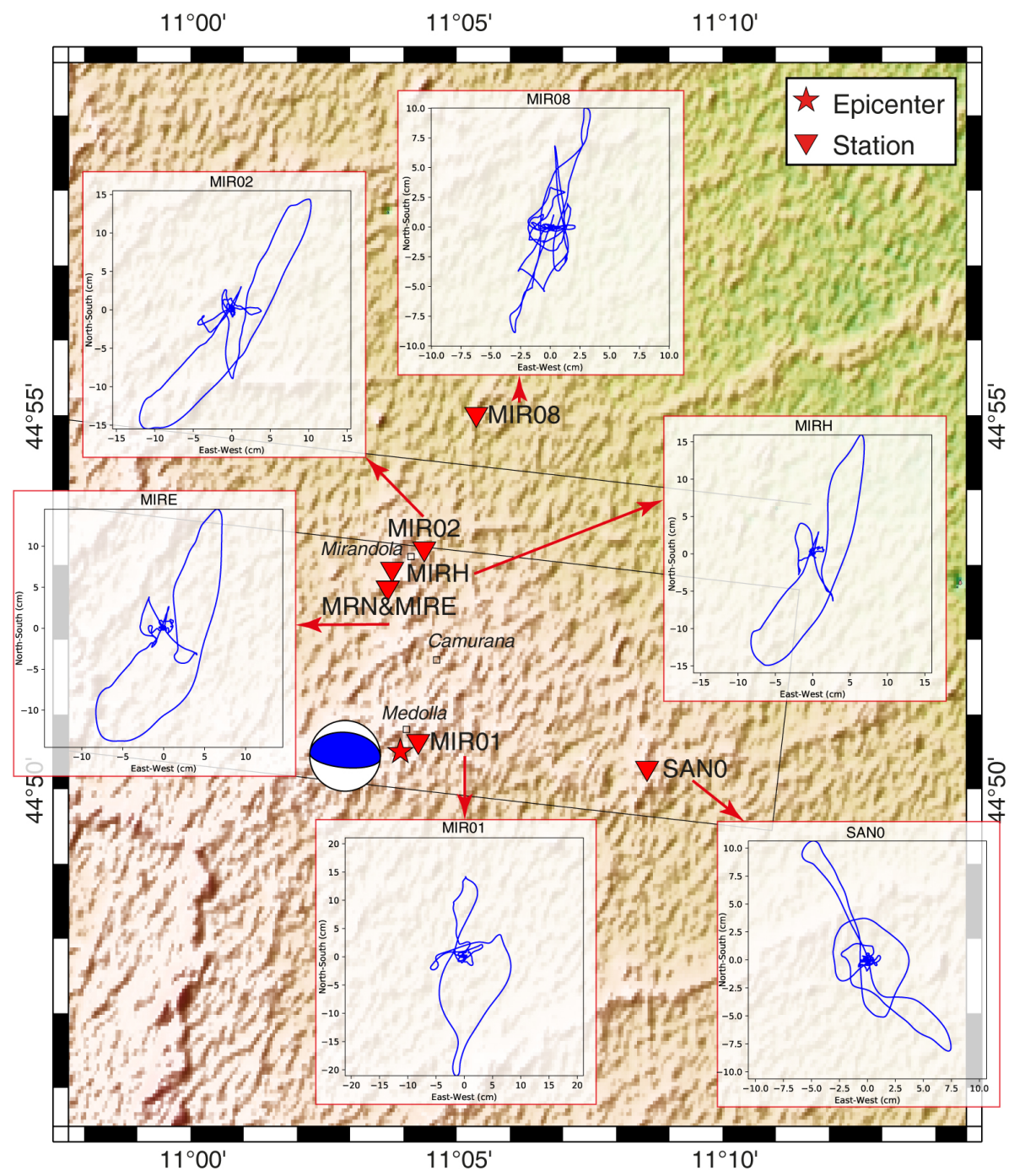

Figure 9. Particle motions of stations with impulsive signals in the 29 May 2012 (07:00) EmiliaRomagna earthquake. Stations MRN and MIRE are very close each other, and they have a very similar plot of the horizontal displacement. 


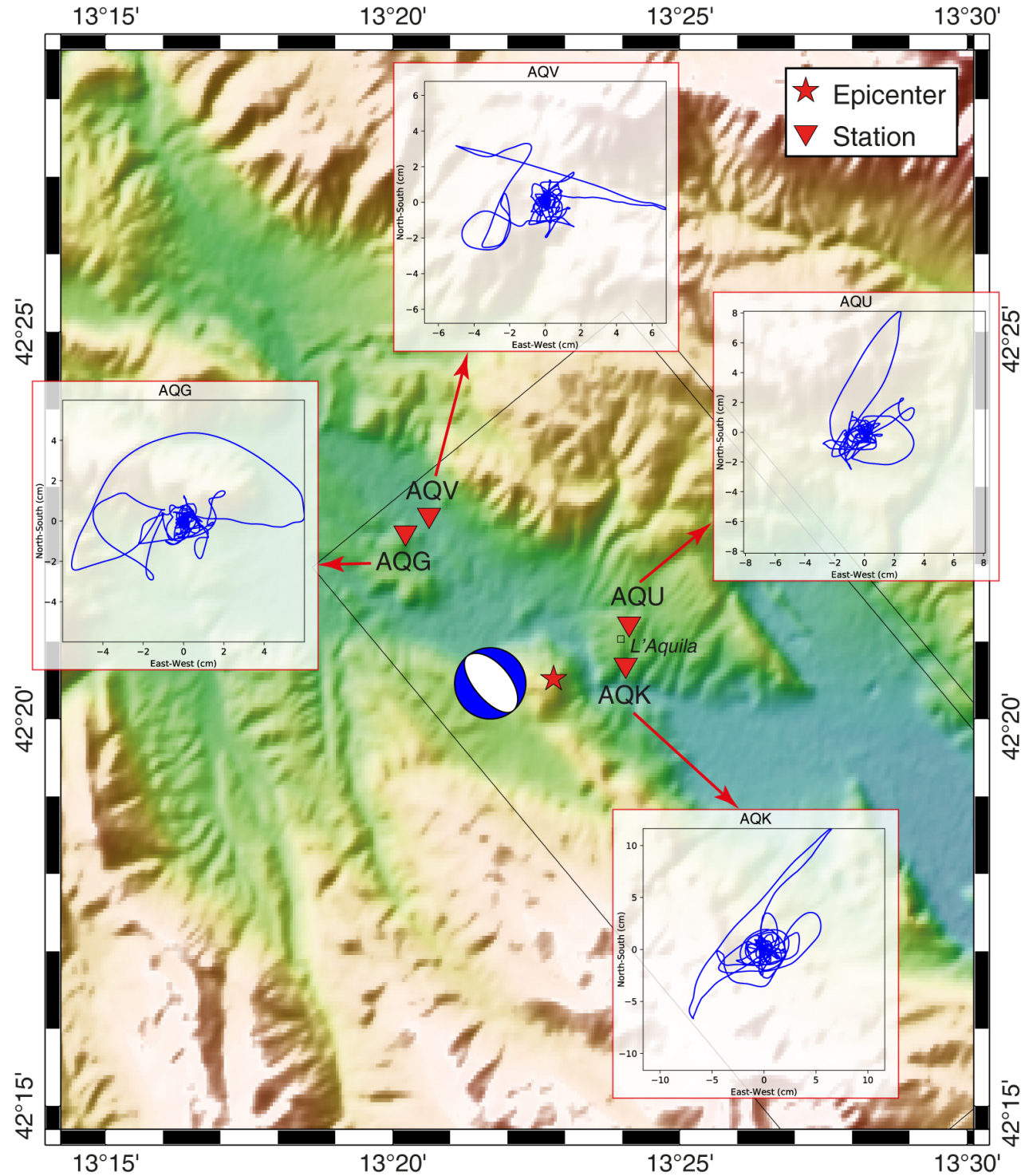

Figure 10. Particle motions of stations of AQG, AQK, AQU, and AQV that are labeled as impulsive in 2009 L'Aquila earthquake.

At the same time, the analysis of the horizontal displacements of the impulsive signals shows that impulsive signals could be differentiated considering their horizontal displacement plots. An empirical observation of the horizontal displacements of impulsive signals suggests to distinguish two principal characteristics of impulsive signals, which could have different effects on structures. This observation shows that most impulsive signals in the 29 May 2012 (07:00) Emilia-Romagna earthquake are characterized by a "forward-back-like displacement" (FBD) (Figure 12b-f), while the earthquake of the 20 May 2012 generated impulses characterized by "spinning-like displacement" (SPD) (Figure 12a). Here, the two displacement characteristics are differentiated considering the shape of the horizontal displacement plot, where FBD refers to impulsive displacements occurring mainly along one directions, while SPD impulsive signals refer to displacements which are more similar to a spinning motion. As a first attempt to identify an automated method for calculating SPD and FBD characteristics, it was used the minimum volume enclosing ellipsoid method [91,92]. This method is applied to calculate the minimum ellipse around a 2D set of points, allowing for some tolerance in the data fit. Then, SPD and FBD are assigned considering the ratio between the major and minor axes of the ellipse (aspect ratio, $a$ ). Indicatively and through 
an empirical evaluation, we identified the following threshold to distinguish between FBD and SPD:

- $\quad a \leq 2$ indicates that the signal can be described as SPD;

- $\quad 2<a<2.5$ can refer both to SPD and FBD;

- $\quad a \geq 2.5$ indicates that the signal can be described as FBD.

Using the above rules, it is possible to observe that during the 30 October 2016 Central Italy earthquake, seismic stations recorded both FBD and SPD impulses, and it is probable that this aspect is connected to local site characteristics. The Authors believe that the dependence of the impulsive signals on site effects should be further investigated, considering also if the site has some effects in facilitating FBD or SPD impulsive signals.

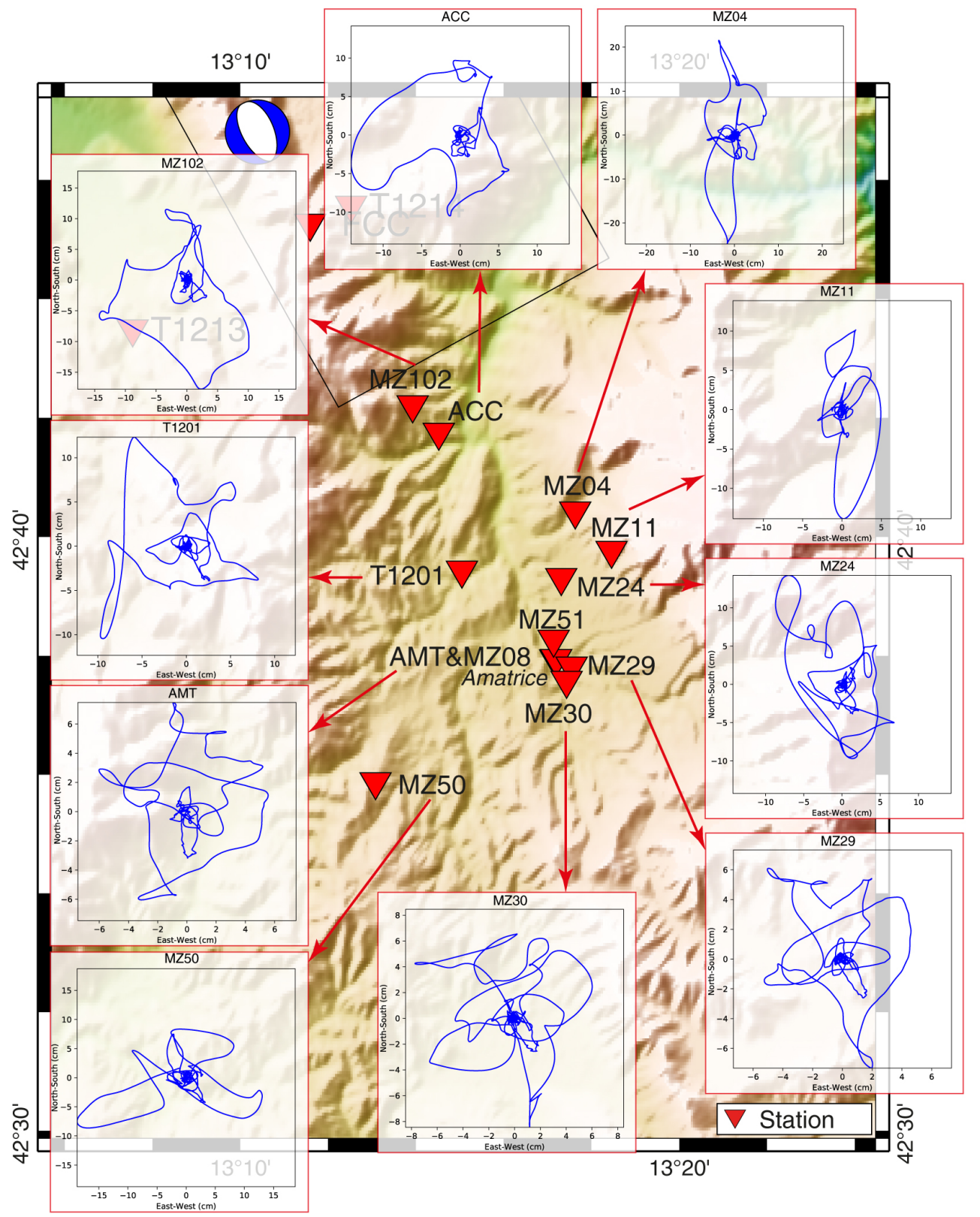

Figure 11. Particle motions of stations of ACC, MZ04, MZ11, MZ24, MZ29, MZ30, MZ50, AMT, T1201, and MZ102 that are labeled as impulsive in Norcia earthquake. Stations AMT and MZ08 are very closed each other and have almost the same plot. The plot of MZ51 station is very similar to the plot of stations AMT and MZ08, and it has been not displayed. 


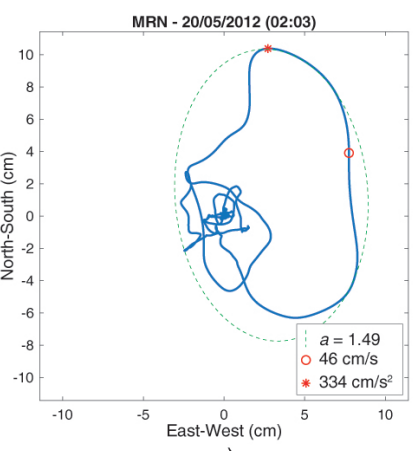

a)

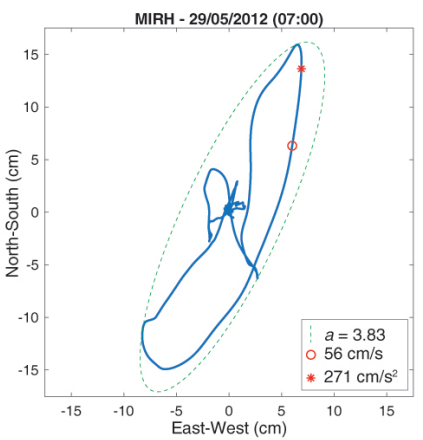

d)

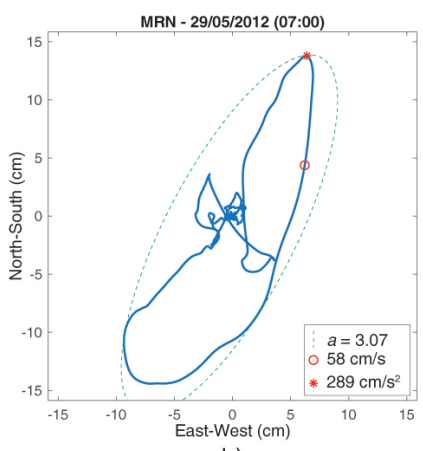

b)

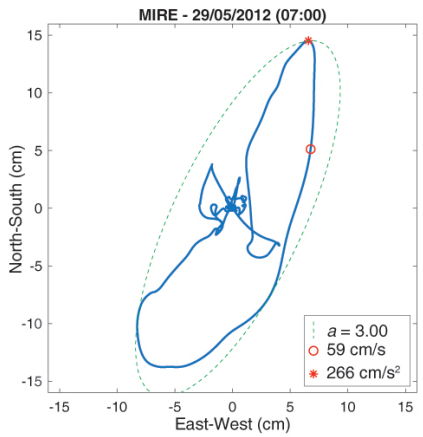

e)

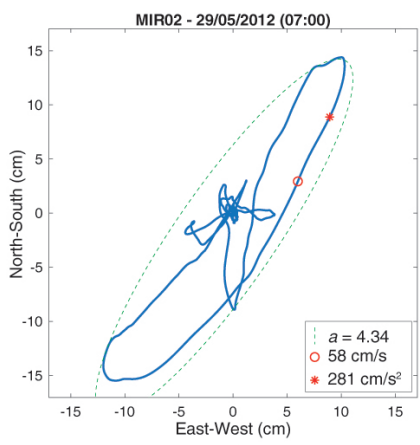

c)

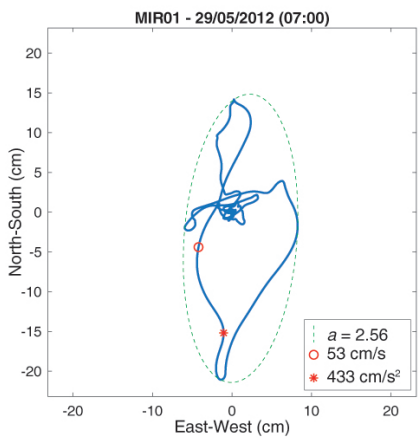

f)

Figure 12. Plot of the horizontal displacements for the pulses recorded during the Emilia 2012 earthquake sequence. The dashed green line shows the minimum enclosing ellipse calculated for each displacement plot, using a tolerance value of 0.01 . The $a$ value is reported for each plot, together with the values of horizontal maximum velocity (red circle) and maximum acceleration (red star). (a) "spinning-like displacement" $(a \leq 2.0)$; (b-f) "forward-back-like displacements" $(a \geq 2.5)$.

In the following, we illustrate some cases that we consider representative in order to show how the different impulsive characteristics could cause diverse typologies of damage to buildings. In masonry wall structural elements (such as an unconnected façade of a church), the effects of seismic solicitations change if the solicitation direction is mainly parallel to the wall principal direction (in plane solicitation) or orthogonal (out of plane solicitation). For this reason, the direction of the ground motion displacement is used as an indicator of the potential presence or absence of in plane effects (which provide a better response of the structural element with respect to the out of plane). In the case of SPD, both in-plane and out of plane effects are possible, while, for FBD, it is possible that the solicitation affects mainly one direction of the structural element. In the following example, we will illustrate the case of FBD pulses with main direction almost parallel to the main direction of church façades. In particular, we discuss qualitatively how the typology of horizontal displacement of the impulsive signal affected three churches damaged in the Emilia-Romagna earthquakes by analyzing the pictures of structural damage acquired after the earthquakes. The three churches are located (Figure 13): two in Mirandola (Santa Maria Maggiore and San Francesco) and one in Camurana (San Luca), a small village in the municipality of Medolla. The two churches in the center of Mirandola are quite similar, concerning dimensions and structural typology. They are both directed along the West-East direction, with a slightly different rotation (Figure 13). After the 20 May, both churches were damaged, and in both cases the façade was detached from the lateral walls of the church (Figure 14a-b). The impulsive signal recorded in the MRN station (about one km away) can be characterized as a SPD horizontal impulsive signal (Figure 12). Maximum horizontal acceleration $\left(334 \mathrm{~cm} / \mathrm{s}^{2}\right)$ is represented by the red star in the displacement plot, while the red circle represents the maximum velocity $(46 \mathrm{~cm} / \mathrm{s})$. In addition, the church of Camurana showed severe damage linked to the detachment of the façade (Figure 14c). The 29 May 2012 (07:00) earthquake hit the already damaged churches, and the impulsive horizontal 
ground motion could be characterized as FBD, with the main direction approximately along the North-North East direction (Figure 12). This direction is almost parallel to the façade of the churches in Mirandola and orthogonal to that of Camurana. Due to the observed characteristics of the ground motion in correspondence of the seismic stations, we suppose that the seismic ground motion at the base of the churches is similar to that recorded by the stations (this assumption could not be made in the Amatrice earthquake, where the characteristics of the impulsive ground motion changed even in few hundreds of meters).

The second earthquake severely increased the damage of the analyzed churches. In this paper, we focus, for the three analyzed churches, on the effects on the façades, which are extremely vulnerable also because the first earthquake detached them from the lateral walls. The façades of Santa Maria Maggiore and of San Francesco did not collapse after the earthquake (Figure $14 \mathrm{~d}-\mathrm{e}$ ), very probably because the main displacement direction of the FBD impulsive ground motion occurred along the longitudinal direction of the façade, allowing an "in-plane" response of the structural element. Conversely, the façade of the church in Camurana was almost orthogonal to the FBD, and this façade collapsed out-ofplane (Figure 14f). As mentioned above, these cases should be studied more in-depth, also considering the effect of cumulative damage as underlined by Grimaz and Malisan [46]; however, it seems reasonable to associate the FBD impulsive signals (and its direction) to the above-defined effects on the structures. It is worth noting that the above considerations are only qualitative and require further larger and quantitative investigation, and that there is the need to refine and improve the algorithm for the automated assignment of FBD and SPD characteristics.

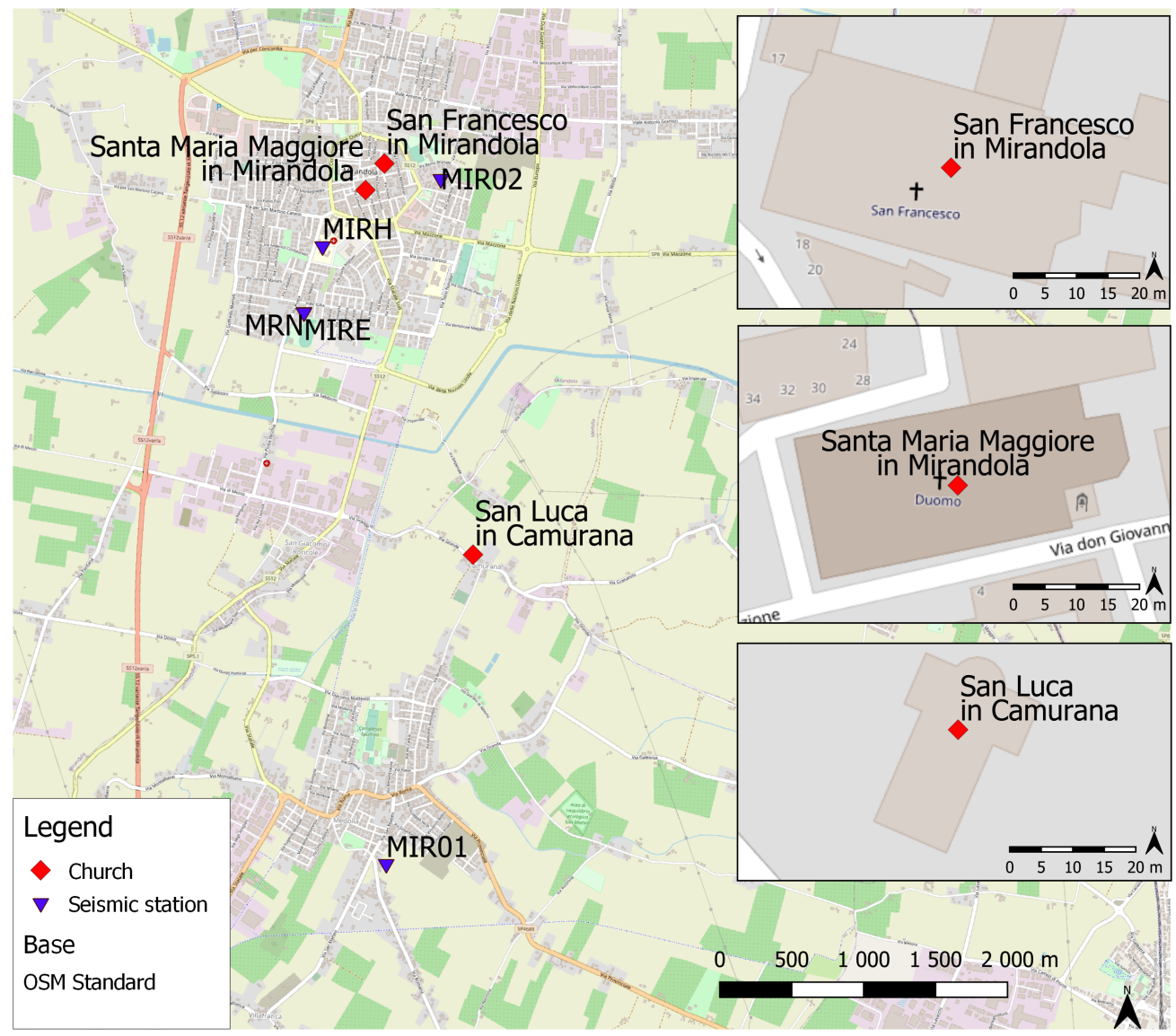

Figure 13. Map of the churches analyzed in the discussion, and relative position with respect to the closest seismic stations which recorded the 29 May earthquake. The map is created by using QGIS software [93]. 
Finally, it is also important to recognize the importance of the vertical ground motion on the damage of buildings; this is particularly true when considering the effects on frictionbased structural typologies, such as pre-cast or stone masonry buildings. Specific studies should be developed also considering the effect of vertical impulsive ground motion on these structures, both for the design of new ones and for the retrofitting of existent ones.
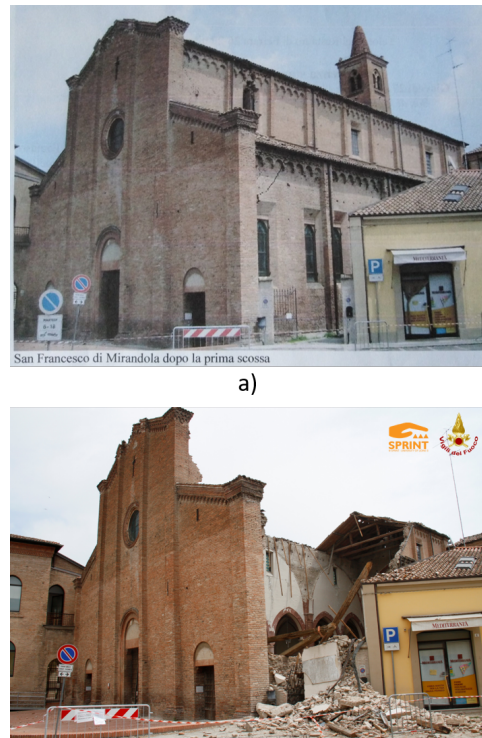

d)
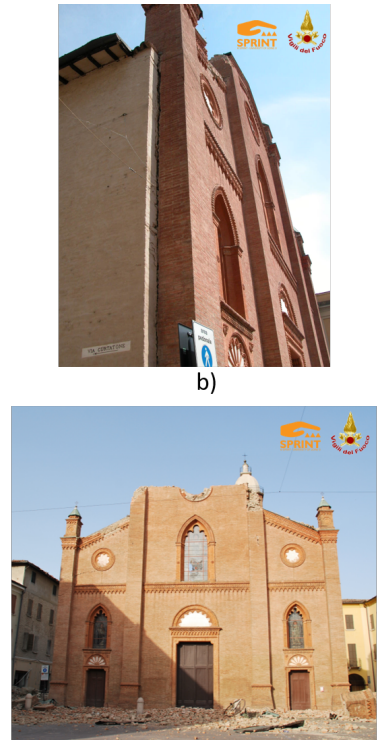

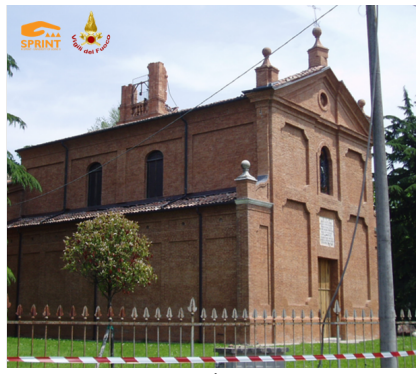

c)

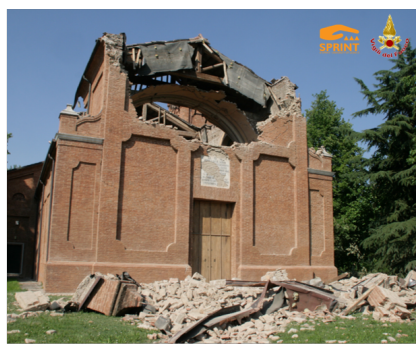

f)

Figure 14. Photos showing the damage of: (a,d) church of San Francesco in Mirandola after the Emilia-Romagna earthquakes of 20 May 2012 (a) and 29 May 2012 (d); (b,e) church of Santa Maria Maggiore in Mirandola after the earthquakes of 20 May 2012 (b) and 29 May 2012 (e); (c,f) church of San Luca in Camurana after the earthquakes of 20 May 2012 (c) and 29 May 2012 (f). The pictures derive from the database of CNVVF-NCP [94], with exception from picture (a) from https:/ / www. italianostramodena.org (accessed on 13 April 2021).

\section{Conclusions}

In this study, we investigate the major earthquakes $\left(M_{w} \geq 5.0\right)$ to identify impulsive signals by using 3 different classification algorithms. In total, more than 15,000 station records are collected from 93 earthquakes, and 13 earthquakes produced at least 1 impulsive signal. All the impulsive signals are produced by normal and reverse fault systems. Number of impulsive signals and their orientations vary, depending on the classification algorithms (Table 1). Due to the unique features, e.g., fling step and directivity effects, of the earthquakes and dense seismic coverage in recent years, many impulsive signals are recorded in near-field areas. We present some preliminary evidence-based considerations about the potential influence of site effects on impulsive signals, focusing mainly on the horizontal component, although there is the need to study in depth also the vertical component of the impulsive motions. We highlight that the horizontal displacement of the impulsive signals could be differentiated considering if the horizontal impulse is characterized by a forward-back-like or a spinning-like displacement. Then, we show how it is possible to develop an a posteriori analysis of the structural damage considering these two typologies of impulsive signals could affect buildings, looking at the damage of three churches hit by the Emilia-Romagna earthquakes in 2012. This study highlights the importance of developing further studies on the impulsive effects in the near field areas, and for this purpose, it is essential to record near fault motions, which will permit to improve the understanding of the damaging effects of earthquakes in near fault regions where the dense population may live. 
Supplementary Materials: The following are available at https://www.mdpi.com/article/10.3390/ geosciences11060261/s1.

Author Contributions: Conceptualization, D.E., P.M., S.G., and G.C.; methodology, D.E.; software, D.E.; validation, D.E., P.M., S.G., and G.C.; formal analysis, D.E. and P.M.; investigation, D.E. and P.M.; resources, D.E. and P.M.; data curation, D.E.; writing-original draft preparation, D.E. and P.M.; writing-review and editing, D.E., P.M., S.G., and G.C.; visualization, D.E. and P.M.; supervision, G.C. and S.G.; project administration, G.C. and S.G.; funding acquisition, G.C. All authors have read and agreed to the published version of the manuscript.

Funding: This study received financial support from the Italian Department of Civil ProtectionPresidency of the Council of Ministers (DPC) and Regional Civil Protection of Regione Autonoma Friuli Venezia Giulia.

Data Availability Statement: Earthquake signals can be retrieved from ITACA database (https: / /itaca.mi.ingv.it/ accessed on 25 May 2021).

Acknowledgments: We would like to thank to the networks of Istituto Nazionale di Geofisica e Vulcanologia (INGV) et al. [95] (3A), Istituto Nazionale Di Geofisica E Vulcanologia (INGV) [96] (4A), UniBAS (BA), CERN Seismic Network (C4), Rete ENEA (E), RESIF [97] (FR), Institut De Physique Du Globe De Paris (IPGP) and Ecole Et Observatoire Des Sciences De La Terre De Strasbourg (EOST) [98] (G), University of Genova [99] (GU), National Observatory of Athens [100] (HL), University of Patras [101] (HP), Presidency of Counsil Of Ministers-Civil Protection Department [102] (IT), INGV Seismological Data Centre [103] (IV), Irpinia Seismic Network (IX), MedNet Project Partner Institutions [104] (MN), Priolo et al. [105] (MZ), Istituto Nazionale Di Oceanografia E Di Geofisica Sperimentale (OGS) And University of Trieste [106] (NI), OGS [107] (OX), RESIF [108] (RA), University of Trieste [109] (RF), Reti accelerometriche centri storici italiani (RR), Province Südtirol (SI), Slovenian Environment Agency [110] (SL), Geological Survey-Provincia Autonoma Di Trento [111] (ST), INGV experiments network (TV), EMERSITO Working Group [112] (XO), and SISMOVALP (ZN) for sharing their data via the ITACA database. We thank CNVVF-NCP for the photos of the damaged churches after the 2012 Emilia-Romagna earthquakes. We would like to thank 3 anonymous reviewers for their constructive comments.

Conflicts of Interest: The authors declare no conflict of interest. The funders had no role in the design of the study; in the collection, analyses, or interpretation of data; in the writing of the manuscript, or in the decision to publish the results.

\author{
Abbreviations \\ The following abbreviations are used in this manuscript: \\ CNVVF Corpo Nazionale dei Vigili del Fuoco (The Italian National Fire Service) \\ FBD Forward-Back-like Displacement \\ ITACA ITalian ACcelerometric Archive \\ NCP Nucleo Coordinamento opere Provvisionali (Coordination Unit for Shoring) \\ PC Principal Component \\ PI Pulse Indicator \\ PGV Peak Ground Velocity \\ SPD Spinning-like Displacement
}

\title{
References
}

1. Somerville, P.G.; Smith, N.F.; Graves, R.W.; Abrahamson, N.A. Accounting for near-fault rupture directivity effects in the development of design ground motions. ASME-PUBLICATIONS-PVP 1995, 319, 67-82.

2. Bolt, B.A.; Abrahamson, N.A. 59 Estimation of strong seismic ground motions. Int. Geophys. 2003, 81, 983-1001. [CrossRef]

3. Mavroeidis, G.P.; Papageorgiou, A.S. A mathematical representation of near-fault ground motions. Bull. Seismol. Soc. Am. 2003, 93, 1099-1131. [CrossRef]

4. Somerville, P.G.; Smith, N.F.; Graves, R.W.; Abrahamson, N.A. Modification of Empirical Strong Ground Motion Attenuation Relations to Include the Amplitude and Duration Effects of Rupture Directivity. Seismol. Res. Lett. 1997, 68, 199-222. [CrossRef]

5. Alavi, B.; Krawinkler, H. Behavior of moment-resisting frame structures subjected to near-fault ground motions. Earthq. Eng. Struct. Dyn. 2004, 33, 687-706. [CrossRef] 
6. Mavroeidis, G.; Dong, G.; Papageorgiou, A. Near-fault ground motions, and the response of elastic and inelastic single-degree-offreedom (SDOF) systems. Earthq. Eng. Struct. Dyn. 2004, 33, 1023-1049. [CrossRef]

7. Gillie, J.; Rodriguez-Marek, A.; McDaniel, C. Strength reduction factors for near-fault forward-directivity ground motions. Eng. Struct. 2010, 32, 273-285. [CrossRef]

8. Hubbard, D.; Mavroeidis, G. Damping coefficients for near-fault ground motion response spectra. Soil Dyn. Earthq. Eng. 2011, 31, 401-417. [CrossRef]

9. Champion, C.; Liel, A. The effect of near-fault directivity on building seismic collapse risk. Earthq. Eng. Struct. Dyn. 2012, 41, 1391-1409. [CrossRef]

10. Kalkan, E.; Kunnath, S.K. Effects of fling step and forward directivity on seismic response of buildings. Earthq. Spectra 2006, 22, 367-390. [CrossRef]

11. Grimaz, S.; Malisan, P. Near field domain effects and their consideration in the international and Italian seismic codes. Boll. Geofis. Teor. Appl. 2014, 55, 717-738. [CrossRef]

12. Alonso-Rodríguez, A.; Miranda, E. Assessment of building behavior under near-fault pulse-like ground motions through simplified models. Soil Dyn. Earthq. Eng. 2015, 79, 47-58. [CrossRef]

13. Cao, Y.; Meza-Fajardo, K.; Mavroeidis, G.; Papageorgiou, A. Effects of wave passage on torsional response of symmetric buildings subjected to near-fault pulse-like ground motions. Soil Dyn. Earthq. Eng. 2016, 88, 109-123. [CrossRef]

14. Cao, Y.; Mavroeidis, G.; Meza-Fajardo, K.; Papageorgiou, A. Accidental eccentricity in symmetric buildings due to wave passage effects arising from near-fault pulse-like ground motions. Earthq. Eng. Struct. Dyn. 2017, 46, 2185-2207. [CrossRef]

15. Iervolino, I.; Baltzopoulos, G.; Chioccarelli, E.; Suzuki, A. Seismic actions on structures in the near-source region of the 2016 central Italy sequence. Bull. Earthq. Eng. 2019, 17, 5429-5447. [CrossRef]

16. Hall, J.F.; Heaton, T.H.; Halling, M.W.; Wald, D.J. Near-Source Ground Motion and its Effects on Flexible Buildings. Earthq. Spectra 1995, 11, 569-605. [CrossRef]

17. Makris, N. Rigidity-plasticity-viscosity: Can electrorheological dampers protect base-isolated structures from near-source ground motions? Earthq. Eng. Struct. Dyn. 1997, 26, 571-591. [CrossRef]

18. Mazza, F. Seismic demand of base-isolated irregular structures subjected to pulse-type earthquakes. Soil Dyn. Earthq. Eng. 2018, 108, 111-129. [CrossRef]

19. Habib, A.; Houri, A.A.; Yildirim, U. Comparative study of base-isolated irregular RC structures subjected to pulse-like ground motions with low and high PGA/PGV ratios. Structures 2021, 31, 1053-1071. [CrossRef]

20. Bhagat, S.; Wijeyewickrema, A.; Subedi, N. Influence of Near-Fault Ground Motions with Fling-Step and Forward-Directivity Characteristics on Seismic Response of Base-Isolated Buildings. J. Earthq. Eng. 2021, 25, 455-474. [CrossRef]

21. Ucak, A.; Mavroeidis, G.; Tsopelas, P. Behavior of a seismically isolated bridge crossing a fault rupture zone. Soil Dyn. Earthq. Eng. 2014, 57, 164-178. [CrossRef]

22. Yang, S.; Mavroeidis, G.; Ucak, A.; Tsopelas, P. Effect of ground motion filtering on the dynamic response of a seismically isolated bridge with and without fault crossing considerations. Soil Dyn. Earthq. Eng. 2017, 92, 183-191. [CrossRef]

23. Falsone, G.; Recupero, A.; Spinella, N. Effects of near-fault earthquakes on existing bridge performances. J. Civ. Struct. Health Monit. 2020, 10, 165-176. [CrossRef]

24. Yang, S.; Mavroeidis, G.; Ucak, A. Analysis of bridge structures crossing strike-slip fault rupture zones: A simple method for generating across-fault seismic ground motions. Earthq. Eng. Struct. Dyn. 2020, 49, 1281-1307. [CrossRef]

25. Zhong, J.; Jiang, L.; Pang, Y.; Yuan, W. Near-fault seismic risk assessment of simply supported bridges. Earthq. Spectra 2020, 36, 1645-1669. [CrossRef]

26. Madan, A.; Hashmi, A. Analytical prediction of the seismic performance of masonry infilled reinforced concrete frames subjected to near-field earthquakes. J. Struct. Eng. 2008, 134, 1569-1581. [CrossRef]

27. Liossatou, E.; Fardis, M. Near-fault effects on residual displacements of RC structures. Earthq. Eng. Struct. Dyn. 2016, 45, 1391-1409. [CrossRef]

28. Hamidi, H.; Karbassi, A.; Lestuzzi, P. Seismic response of RC buildings subjected to fling-step in the near-fault region. Struct. Concr. 2020, 21, 1919-1937. [CrossRef]

29. Shahaki Kenari, M.; Celikag, M. Correlation of Ground Motion Intensity Measures and Seismic Damage Indices of MasonryInfilled Steel Frames. Arab. J. Sci. Eng. 2019, 44, 5131-5150. [CrossRef]

30. Bilgin, H.; Hysenlliu, M. Comparison of near and far-fault ground motion effects on low and mid-rise masonry buildings. J. Build. Eng. 2020, 30. [CrossRef]

31. Augenti, N.; Parisi, F. Learning from Construction Failures due to the 2009 L'Aquila, Italy, Earthquake. J. Perform. Constr. Facil. 2010, 24, 536-555. [CrossRef]

32. Kaplan, H.; Bilgin, H.; Yilmaz, S.; Binici, H.; Öztas, A. Structural damages of L'Aquila (Italy) earthquake. Nat. Hazards Earth Syst. Sci. 2010, 10, 499-507. [CrossRef]

33. Carocci, C.F. Small centres damaged by 2009 L'Aquila earthquake: On site analyses of historical masonry aggregates. Bull. Earthq. Eng. 2012, 10, 45-71. [CrossRef]

34. Ricci, P.; De Luca, F.; Verderame, G.M. 6th April 2009 L'Aquila earthquake, Italy: Reinforced concrete building performance. Bull. Earthq. Eng. 2011, 9, 285-305. [CrossRef] 
35. Brandonisio, G.; Lucibello, G.; Mele, E.; Luca, A.D. Damage and performance evaluation of masonry churches in the 2009 L'Aquila earthquake. Eng. Fail. Anal. 2013, 34, 693-714. [CrossRef]

36. Grimaz, S.; Maiolo, A. The impact of the 6 April 2009 l'Aquila earthquake (Italy) on the industrial facilities and life lines. Considerations in terms of NaTech risk. Chem. Eng. Trans. 2010, 19, 279-284. [CrossRef]

37. Cattari, S.; Degli Abbati, S.; Ferretti, D.; Lagomarsino, S.; Ottonelli, D.; Tralli, A. Damage assessment of fortresses after the 2012 Emilia earthquake (Italy). Bull. Earthq. Eng. 2014, 12, 2333-2365. [CrossRef]

38. Lagomarsino, S. Damage assessment of churches after L'Aquila earthquake (2009). Bull. Earthq. Eng. 2012, 10, 73-92. [CrossRef]

39. Parisi, F.; De Luca, F.; Petruzzelli, F.; De Risi, R.; Chioccarelli, E.; Iervolino, I. Field Inspection after the May 20 th and 29 th 2012 Emilia-Romagna Earthquakes; Italian Network of Earthquake Engineering University Laboratories: Naples, Italy, 2012.

40. Sorrentino, L.; Liberatore, L.; Decanini, L.D.; Liberatore, D. The performance of churches in the 2012 Emilia earthquakes. Bull. Earthq. Eng. 2014, 12, 2299-2331. [CrossRef]

41. Milani, G.; Valente, M. Failure analysis of seven masonry churches severely damaged during the 2012 Emilia-Romagna (Italy) earthquake: Non-linear dynamic analyses vs conventional static approaches. Eng. Fail. Anal. 2015, 54, 13-56. [CrossRef]

42. Valente, M.; Barbieri, G.; Biolzi, L. Damage assessment of three medieval churches after the 2012 Emilia earthquake. Bull. Earthq. Eng. 2017, 15, 2939-2980. [CrossRef]

43. Bournas, D.A.; Negro, P.; Taucer, F.F. Performance of industrial buildings during the Emilia earthquakes in Northern Italy and recommendations for their strengthening. Bull. Earthq. Eng. 2014, 12, 2383-2404. [CrossRef]

44. Ercolino, M.; Magliulo, G.; Manfredi, G. Failure of a precast RC building due to Emilia-Romagna earthquakes. Eng. Struct. 2016, 118, 262-273. [CrossRef]

45. Savoia, M.; Buratti, N.; Vincenzi, L. Damage and collapses in industrial precast buildings after the 2012 Emilia earthquake. Eng. Struct. 2017, 137, 162-180. [CrossRef]

46. Grimaz, S.; Malisan, P. How could cumulative damage affect the macroseismic assessment? Bull. Earthq. Eng. 2016, 15, 1-17. [CrossRef]

47. Sorrentino, L.; Cattari, S.; da Porto, F.; Magenes, G.; Penna, A. Seismic behaviour of ordinary masonry buildings during the 2016 central Italy earthquakes. Bull. Earthq. Eng. 2019, 17, 5583-5607. [CrossRef]

48. Jain, A.; Acito, M.; Chesi, C. Seismic sequence of 2016-17: Linear and non-linear interpretation models for evolution of damage in San Francesco church, Amatrice. Eng. Struct. 2020, 211, 110418. [CrossRef]

49. Masi, A.; Chiauzzi, L.; Santarsiero, G.; Manfredi, V.; Biondi, S.; Spacone, E.; Del Gaudio, C.; Ricci, P.; Manfredi, G.; Verderame, G.M. Seismic response of RC buildings during the Mw 6.0 August 24, 2016 Central Italy earthquake: The Amatrice case study. Bull. Earthq. Eng. 2019, 17, 5631-5654. [CrossRef]

50. Baker, J.W. Quantitative Classification of Near-Fault Ground Motions Using Wavelet Analysis. Bull. Seismol. Soc. Am. 2007, 97, 1486-1501. [CrossRef]

51. Shahi, S.K.; Baker, J.W. An Efficient Algorithm to Identify Strong-Velocity Pulses in Multicomponent Ground Motions. Bull. Seismol. Soc. Am. 2014, 104, 2456-2466. [CrossRef]

52. Chang, Z.; Sun, X.; Zhai, C.; Zhao, J.X.; Xie, L. An improved energy-based approach for selecting pulse-like ground motions. Earthq. Eng. Struct. Dyn. 2016, 45, 2405-2411. [CrossRef]

53. Ertuncay, D.; Costa, G. An alternative pulse classification algorithm based on multiple wavelet analysis. J. Seismol. 2019, 23, 929-942. [CrossRef]

54. Somerville, P.G. Magnitude scaling of the near fault rupture directivity pulse. Phys. Earth Planet. Inter. 2003, 137, 201-212. [CrossRef]

55. Bray, J.D.; Rodriguez-Marek, A. Characterization of forward-directivity ground motions in the near-fault region. Soil Dyn. Earthq. Eng. 2004, 24, 815-828. [CrossRef]

56. Halldórsson, B.; Mavroeidis, G.P.; Papageorgiou, A.S. Near-fault and far-field strong ground-motion simulation for earthquake engineering applications using the specific barrier model. J. Struct. Eng. 2011, 137, 433-444. [CrossRef]

57. Tang, Y.; Zhang, J. Response spectrum-oriented pulse identification and magnitude scaling of forward directivity pulses in near-fault ground motions. Soil Dyn. Earthq. Eng. 2011, 31, 59-76. [CrossRef]

58. Cork, T.G.; Kim, J.H.; Mavroeidis, G.P.; Kim, J.K.; Halldorsson, B.; Papageorgiou, A.S. Effects of tectonic regime and soil conditions on the pulse period of near-fault ground motions. Soil Dyn. Earthq. Eng. 2016, 80, 102-118. [CrossRef]

59. Sgobba, S.; Lanzano, G.; Pacor, F.; Felicetta, C. An Empirical Model to Account for Spectral Amplification of Pulse-Like Ground Motion Records. Geosciences 2021, 11, 15. [CrossRef]

60. Fayjaloun, R.; Causse, M.; Voisin, C.; Cornou, C.; Cotton, F. Spatial Variability of the Directivity Pulse Periods Observed during an Earthquake. Bull. Seismol. Soc. Am. 2017, 107, 308-318. [CrossRef]

61. Iervolino, I.; Cornell, C.A. Probability of Occurrence of Velocity Pulses in Near-Source Ground Motions. Bull. Seismol. Soc. Am. 2008, 98, 2262-2277. [CrossRef]

62. Ertuncay, D.; Costa, G. Determination of near-fault impulsive signals with multivariate naïve Bayes method. Nat. Hazards 2021, 1-18. [CrossRef]

63. Luzi, L.; Puglia, R.; Russo, E.; D’Amico, M.; Felicetta, C.; Pacor, F.; Lanzano, G.; Çeken, U.; Clinton, J.; Costa, G.; et al. The engineering strong-motion database: A platform to access pan-European accelerometric data. Seismol. Res. Lett. 2016, 87, 987-997. [CrossRef] 
64. Pacor, F.; Paolucci, R.; Luzi, L.; Sabetta, F.; Spinelli, A.; Gorini, A.; Nicoletti, M.; Marcucci, S.; Filippi, L.; Dolce, M. Overview of the Italian strong motion database. Bull Earthq. Eng. 2011, 9, 1723-1739. [CrossRef]

65. Rovida, A.; Locati, M.; Camassi, R.; Lolli, B.; Gasperini, P. The Italian earthquake catalogue CPTI15. Bull. Earthq. Eng. 2020, 18, 2953-2984. [CrossRef]

66. Goldstein, P.; Dodge, D.; Firpo, M.; Minner, L. 85.5 SAC2000: Signal processing and analysis tools for seismologists and engineers. In International Geophysics; Elsevier: Amsterdam, The Netherlands, 2003; Volume 81, pp. 1613-1614. [CrossRef]

67. Boore, D.M.; Watson-Lamprey, J.; Abrahamson, N.A. Orientation-independent measures of ground motion. Bull. Seismol. Soc. Am. 2006, 96, 1502-1511. [CrossRef]

68. Paolucci, R.; Pacor, F.; Puglia, R.; Ameri, G.; Cauzzi, C.; Massa, M. Record processing in ITACA, the new Italian strong-motion database. In Earthquake Data in Engineering Seismology; Springer: Berlin/Heidelberg, Germany, 2011; pp. 99-113.

69. Zhai, C.; Chang, Z.; Li, S.; Chen, Z.; Xie, L. Quantitative Identification of Near-Fault Pulse-Like Ground Motions Based on Energy. Bull. Seismol. Soc. Am. 2013, 103, 2591-2603. [CrossRef]

70. Grimaz, S.; Malisan, P. Advancements from a posteriori studies on the damage to buildings caused by the 1976 Friuli earthquake (north-eastern Italy). Boll. Geofis. Teor. Appl. 2018, 59, 505-526. [CrossRef]

71. Database of Individual Seismogenic Sources (DISS), Version 3.1. 1: A Compilation of Potential Sources for Earthquakes Larger Than M 5.5 in Italy and Surrounding Areas. 2010. Available online: http:/ / diss.rm.ingv.it/diss/ (accessed on 25 May 2021).

72. Uieda, L.; Tian, D.; Leong, W.J.; Toney, L.; Newton, T.; Wessel, P. PyGMT: A Python interface for the Generic Mapping Tools. 2020. Available online: https:/ / www.pygmt.org/ (accessed on 25 May 2021).

73. Ameri, G.; Emolo, A.; Pacor, F.; Gallovic, F. Ground-Motion Simulations for the 1980 M 6.9 Irpinia Earthquake (Southern Italy) and Scenario Events. Bull. Seismol. Soc. Am. 2011, 101, 1136-1151. [CrossRef]

74. De Luca, G.; Marcucci, S.; Milana, G.; Sano, T. Evidence of low-frequency amplification in the city of L'Aquila, Central Italy, through a multidisciplinary approach including strong-and weak-motion data, ambient noise, and numerical modeling. Bull. Seismol. Soc. Am. 2005, 95, 1469-1481. [CrossRef]

75. Akinci, A.; Malagnini, L.; Sabetta, F. Characteristics of the strong ground motions from the 6 April 2009 L'Aquila earthquake, Italy. Soil Dyn. Earthq. Eng. 2010, 30, 320-335. [CrossRef]

76. Lanzo, G.; Pagliaroli, A. Seismic site effects at near-fault strong-motion stations along the Aterno River Valley during the Mw= 6.32009 L'Aquila earthquake. Soil Dyn. Earthq. Eng. 2012, 40, 1-14. [CrossRef]

77. de Normalisation, C.C.E. Eurocode 8: Design of Structures for Earthquake Resistance-Part 1: General Rules, Seismic Actions and Rules for Buildings; European Committee for Standardization: Brussels, Belgium, 2004.

78. Ameri, G.; Massa, M.; Bindi, D.; D'Alema, E.; Gorini, A.; Luzi, L.; Marzorati, S.; Pacor, F.; Paolucci, R.; Puglia, R.; et al. The 6 April 2009 Mw 6.3 L'Aquila (central Italy) earthquake: Strong-motion observations. Seismol. Res. Lett. 2009, 80, 951-966. [CrossRef]

79. Ameri, G.; Gallovič, F.; Pacor, F. Complexity of the Mw 6.3 2009 L'Aquila (central Italy) earthquake: 2. Broadband strong motion modeling: L'AQUILA EARTHQUAKE-BROADBAND MODELING. J. Geophys. Res. Solid Earth 2012, 117. [CrossRef]

80. Pezzo, G.; Merryman Boncori, J.P.; Tolomei, C.; Salvi, S.; Atzori, S.; Antonioli, A.; Trasatti, E.; Novali, F.; Serpelloni, E.; Candela, L.; et al. Coseismic Deformation and Source Modeling of the May 2012 Emilia (Northern Italy) Earthquakes. Seismol. Res. Lett. 2013, 84, 645-655. [CrossRef]

81. Paolucci, R.; Mazzieri, I.; Smerzini, C. Anatomy of strong ground motion: Near-source records and three-dimensional physicsbased numerical simulations of the $M_{\mathrm{w}}$ 6.0 2012 May 29 Po Plain Earthquake, Italy. Geophys. J. Int. 2015, 203, $2001-2020$. [CrossRef]

82. Kaklamanos, J.; Baise, L.G.; Boore, D.M. Estimating Unknown Input Parameters when Implementing the NGA Ground-Motion Prediction Equations in Engineering Practice. Earthq. Spectra 2011, 27, 1219-1235. [CrossRef]

83. Ronald Abraham, J.; Lai, C.G.; Papageorgiou, A. Basin-effects observed during the 2012 Emilia earthquake sequence in Northern Italy. Soil Dyn. Earthq. Eng. 2015, 78, 230-242. [CrossRef]

84. Dreger, D.; Hurtado, G.; Chopra, A.; Larsen, S. Near-field across-fault seismic ground motions. Bull. Seismol. Soc. Am. 2011, 101, 202-221. [CrossRef]

85. Gallovič, F.; Valentová, L.; Ampuero, J.P.; Gabriel, A.A. Bayesian dynamic finite-fault inversion: 2. Application to the 2016 Mw 6.2 Amatrice, Italy, earthquake. J. Geophys. Res. Solid Earth 2019, 124, 6970-6988. [CrossRef]

86. Spagnuolo, E.; Cirella, A.; Akinci, A. Investigating the effectiveness of rupture directivity during the August $24,2016 \mathrm{Mw} 6.0$ central Italy earthquake. Ann. Geophys. 2016, 59. [CrossRef]

87. D'Amico, M.; Felicetta, C.; Schiappapietra, E.; Pacor, F.; Gallovič, F.; Paolucci, R.; Puglia, R.; Lanzano, G.; Sgobba, S.; Luzi, L. Fling Effects from Near-Source Strong-Motion Records: Insights from the 2016 Mw 6.5 Norcia, Central Italy, Earthquake. Seismol. Res. Lett. 2019, 90, 659-671. [CrossRef]

88. Tinti, E.; Scognamiglio, L.; Michelini, A.; Cocco, M. Slip heterogeneity and directivity of the $M_{L}$ 6.0, 2016, Amatrice Earthq. Estim. Rapid Finite-Fault Inversion: Rupture Process 2016 Amatrice Event. Geophys. Res. Lett. 2016, 43, 10745-10752. [CrossRef]

89. Chiaraluce, L.; Di Stefano, R.; Tinti, E.; Scognamiglio, L.; Michele, M.; Casarotti, E.; Cattaneo, M.; De Gori, P.; Chiarabba, C.; Monachesi, G.; et al. The 2016 Central Italy Seismic Sequence: A First Look at the Mainshocks, Aftershocks, and Source Models. Seismol. Res. Lett. 2017, 88, 757-771. [CrossRef]

90. Rodriguez-Marek, A.; Bray, J. Seismic site response for near-fault forward directivity ground motions. J. Geotech. Geoenviron. Eng. 2006, 132, 1611-1620. [CrossRef] 
91. Moshtagh, N. Minimum Volume Enclosing Ellipsoid. MATLAB Central File Exchange. 2021. Available online: https://www. mathworks.com/matlabcentral/fileexchange/9542-minimum-volume-enclosing-ellipsoid (accessed on 25 May 2021).

92. Ahipaşaoğlu, S. Fast algorithms for the minimum volume estimator. J. Glob. Optim. 2015, 62, 351-370. [CrossRef]

93. QGIS Development Team. QGIS Geographic Information System. 2009. Available online: https://qgis.org/ (accessed on 25 May 2021).

94. Grimaz, S.; Malisan, P.; Bolognese, C.; Ponticelli, L.; Cavriani, M.; Mannino, E.; Munaro, L. The short-term countermeasures system of the Italian national fire service for post-earthquake response. Boll. Geofis. Teor. Appl. 2016, 57, 161-182. [CrossRef]

95. Istituto Nazionale di Geofisica e Vulcanologia (INGV); Istituto di Geologia Ambientale e Geoingegneria (CNR-IGAG); Istituto per la Dinamica dei Processi Ambientali (CNR-IDPA); Istituto di Metodologie per L'Analisi Ambientale (CNR-IMAA); Agenzia Nazionale per le nuove tecnologie, L'energia e lo Sviluppo Economico Sostenibile (ENEA). Rete del Centro di Microzonazione Sismica (CentroMZ), Sequenza Sismica del 2016 in Italia Centrale. 2018. Available online: https://www.fdsn.org/networks / detail/3A_2016 (accessed on 25 May 2021). [CrossRef]

96. Istituto Nazionale Di Geofisica E Vulcanologia (INGV). Emersito Seismic Network for Site Effect Studies in L'Aquila Town (Central Italy). 2009. Available online: https://www.fdsn.org/networks/detail/4A_2009/ (accessed on 25 May 2021).

97. RESIF. RESIF-RLBP French Broad-Band Network, RESIF-RAP Strong Motion Network and Other Seismic Stations in Metropolitan France. 1995. Available online: https:/ / www.fdsn.org/networks/detail/FR/ (accessed on 25 May 2021).

98. Institut De Physique Du Globe De Paris (IPGP); Ecole Et Observatoire Des Sciences De La Terre De Strasbourg (EOST). GEOSCOPE, French Global Network of Broad Band Seismic Stations. 1982. Available online: https://www.fdsn.org/networks/detail/G/ (accessed on 25 May 2021).

99. University of Genova. Regional Seismic Network of North Western Italy. 1967. Available online: https://www.fdsn.org/ networks/detail/GU/ (accessed on 25 May 2021).

100. National Observatory of Athens. National Observatory of Athens Seismic Network, 1997. Available online: https://www.fdsn. org/networks/detail/HL/ (accessed on 25 May 2021).

101. University of Patras. PSLNET, Permanent Seismic Network Operated by the University of Patras, Greece. 2000. Available online: https:/ / www.fdsn.org/networks / detail/HP/ (accessed on 25 May 2021).

102. Presidency of Counsil of Ministers-Civil Protection Department. Italian Strong Motion Network. 1972. Available online: https: / / www.fdsn.org/networks/detail/IT/ (accessed on 25 May 2021).

103. INGV Seismological Data Centre. Rete Sismica Nazionale (RSN). 1997. Available online: https://www.fdsn.org/networks / detail/IV/ (accessed on 25 May 2021).

104. MedNet Project Partner Institutions. Mediterranean Very Broadband Seismographic Network (MedNet). 1988. Available online: https: / / www.fdsn.org/networks/detail/MN/ (accessed on 25 May 2021).

105. Priolo, E.; Laurenzano, G.; Barnaba, C.; Bernardi, P.; Moratto, L.; Spinelli, A. OASIS: The OGS archive system of instrumental seismology. Seismol. Res. Lett. 2015, 86, 978-984. [CrossRef]

106. Istituto Nazionale di Oceanografia e di Geofisica Sperimentale (OGS) and University of Trieste. North-East Italy Broadband Network. 2002. Available online: https:/ / www.fdsn.org/networks/detail/NI/ (accessed on 25 May 2021).

107. OGS. North-East Italy Seismic Network. 2016. Available online: https://www.fdsn.org/networks/detail/OX/ (accessed on 25 May 2021). [CrossRef]

108. RESIF. RESIF-RAP French Accelerometric Network. 1995. Available online: https://www.fdsn.org/networks/detail/RA/ (accessed on 25 May 2021).

109. University of Trieste. Friuli Venezia Giulia Accelerometric Network. 1993. Available online: https://www.fdsn.org/networks/ detail/RF/ (accessed on 25 May 2021).

110. Slovenian Environment Agency. Seismic Network of the Republic of Slovenia. 2001. Available online: https://www.fdsn.org/ networks/detail/SL/ (accessed on 25 May 2021).

111. Geological Survey-Provincia Autonoma Di Trento. Trentino Seismic Network. 1981. Available online: https://www.fdsn.org/ networks/detail/ST/ (accessed on 25 May 2021).

112. EMERSITO Working Group. Rete sismica del gruppo EMERSITO, Sequenza Sismica del 2016 in Italia Centrale. 2018. Available online: https:/ / www.fdsn.org/networks / detail/XO_2016/ (accessed on 25 May 2021). [CrossRef] 